\title{
NOVOOBJAVENÉ SÍDLISKOVÉ NÁLEZY SKUPINY LAŽŇANY Z RUSKEJ, OKRES MICHALOVCE ${ }^{1}$
}

\author{
Eva Horváthová - Lýdia Gačková
}

DOI: https://doi.org/10.31577/szausav.2019.suppl.1.13

Keywords: Southeastern Slovakia, turn of the Early and Middle Eneolithic, Lažňany group, settlement features

\section{Newly discovered settlement finds of the Lažňany group from Ruská, Michalovce district}

Archeológia Zemplín, s. r. o., company carried out a rescue excavation in Ruská, Čierna zem site in 2008 and 2009. In two investigation seasons, it documented 122 polycultural features in the body of the gas pipeline structure. Seven out of 42 prehistoric features were hiding archaeological sources attributed to the Hunyadihalom - Lažňany settlement horizon. The site of Čierna zem is one of the few archaeological sites situated north of the Hungarian region of BorsodAbaúj-Zemplén with completely documented settlement features from the turn of the Early and Middle Eneolithic. The archaeological investigation in Ruská enabled us to deal with the topic again more than 37 years after assessment and publication of previously known finds from the Lažňany group burial grounds in Eastern Slovakia.

\section{ZÁKLADNÉ INFORMÁCIE O LOKALITE}

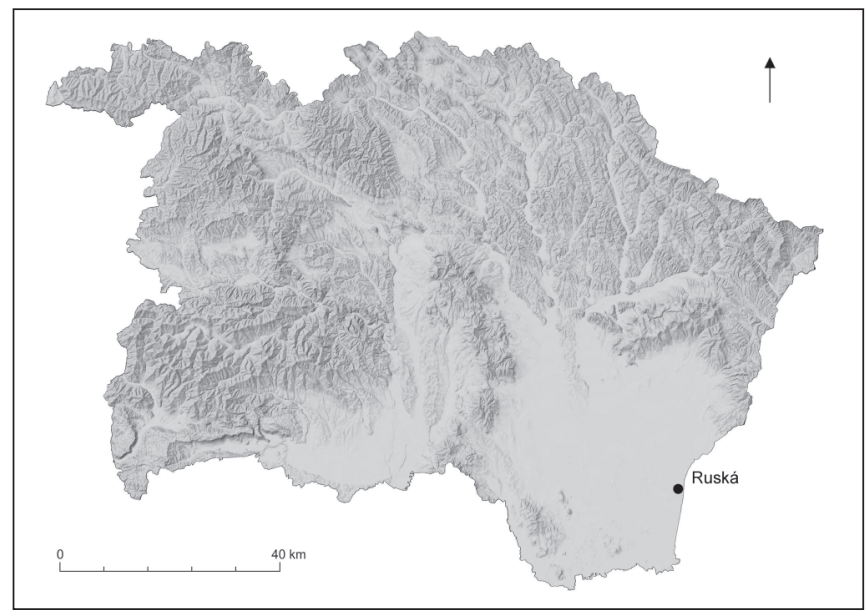

Obr. 1. Ruská, okr. Michalovce. Situovanie lokality na slepej mape východného Slovenska.

Geologická stavba plochy v mieste výskumu pozostáva z kvartérnych fluviálnych sedimentov a nivných sedimentov dnových akumulácii v nivách ${ }^{3}$ (Baňacký a i. 1988). Pôdny pokryv tvoria hnedozeme pseudoglejové a pseudogleje. Dominantnými pôdami v najbližšom okolí sú fluvizeme typické a lokálne fluvizeme glejové a arenické (Granec/Šurina 1999). Charakteristický typ reliéfu krajiny predstavuje rovina. Z hladiska klimatických podmienok sa obec nachádza v teplej suchej oblasti s chladnou zimou.

\footnotetext{
1 Štúdia bola podporená Agentúrou na podporu výskumu a vývoja na základe Zmluvy č. APVV-18-0276, ako aj Vedeckou grantovou agentúrou Ministerstva školstva, vedy, výskumu a športu Slovenskej republiky a Slovenskej akadémie vied v rámci grantového projektu VEGA č. 2/0084/18.

2 Pozri mapu M-34-129-A-d, mierka 1 : 25 000, rok vydania 1957.

3 Geologická mapa Slovenska.
} 


\section{HISTÓRIA VÝSKUMU}

V Ruskej sa v minulosti vo viacerých polohách odkryli praveké až včasnohistorické objekty. V polohe Pri cintoríne boli objavené zlomky keramiky kultúry Suciu de Sus a tri včasnostredoveké objekty z 8 . až 9. stor. (Béreš/Kaminská/lličný 2000, 34; Šiška 1977, 272). K narušeniu sídliskových jám došlo aj v polohe Mostový riadok, situovanej približne $1,3 \mathrm{~km}$ severozápadným smerom od stredu obce. V týchto miestach bol preskúmaný zahĺbený objekt z 10. až 12 . stor., ktorý porušil staršie kultúrne nezaradené eneolitické osídlenie (Vizdal, M. 1986, 244). Z povrchového zberu v polohe Farský vrch pochádza ojedinelý črep z doby rímskej a zlomok hornej časti nádoby zdobený dvoma radmi vlnoviek a polovica korálika z 9. až 10. stor. (Vizdal, M. 1986).

Najvýraznejšie osídlenie chotára registrujeme v polohe Čierna zem, ktorá bola rekognoskovaná v súvislosti s výstavbou a rekonštrukciou plynovodných potrubí v rokoch 1998, 2008 a 2009 (obr. 2). V priebehu prvej výskumnej sezóny realizovanej pracovníkmi Archeologického ústavu SAV v roku 1998 sa v uvedenej polohe preskúmalo 24 objektov zo štyroch chronologických úsekov: sedem z doby bronzovej, jeden z doby laténskej, pät z doby rímskej, devät z 9 . stor. a dalšie dva nedatované objekty neobsahovali archeologický materiál (Bérěs/KaminskálUličný 2000, 34). Nasledujúce výskumy na lokalite viedla Lýdia Gačková s Petrom Šimčíkom v spolupráci s Dušanom Bombom (v tom čase všetci zo spoločnosti Archeológia Zemplín, s. r. o.), ktorí v roku 2008 objavili 26 objektov a počas pokračovania výskumu v roku 2009 sa počet

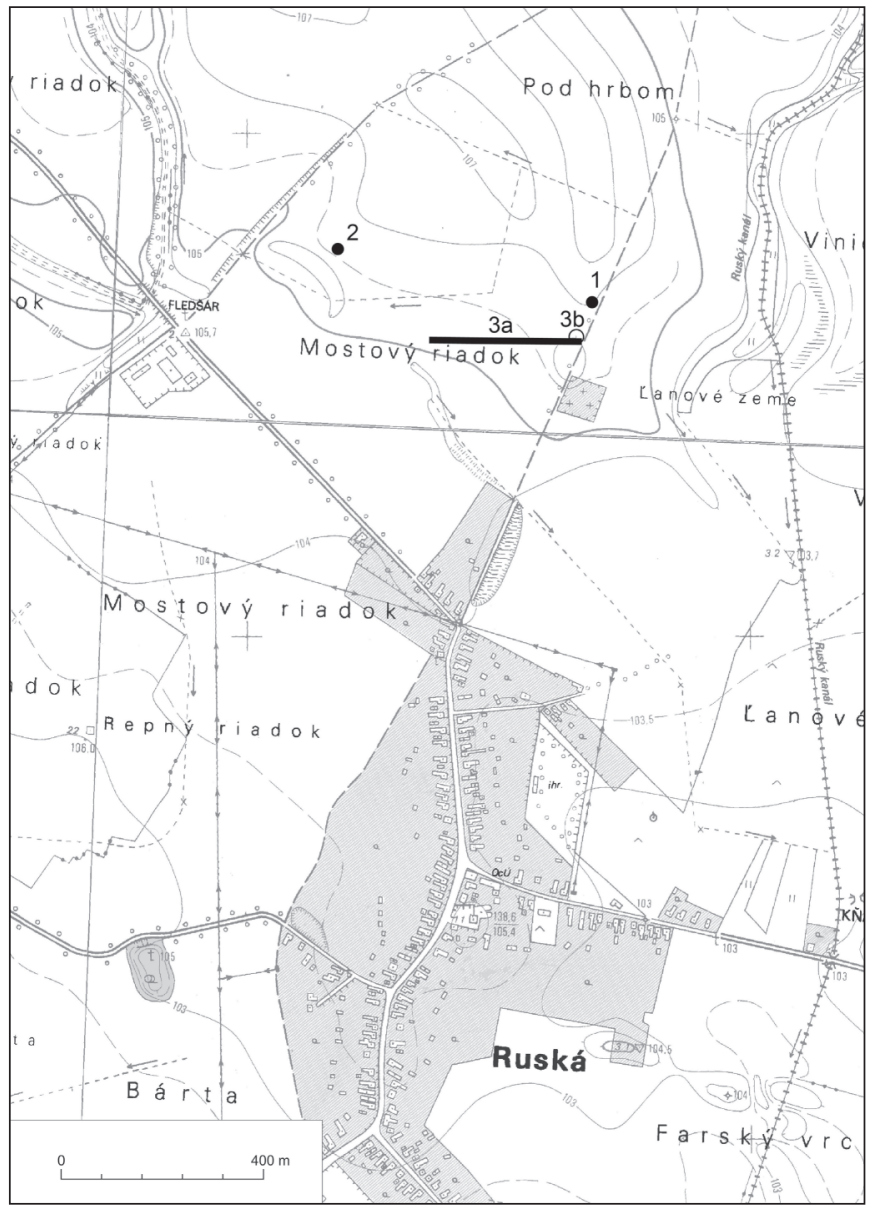

Obr. 2. Ruská, okr. Michalovce. Výsek z mapy 38-41-18. 1 poloha Pri cintoríne, miesto výskumu v roku 1998; 2 - poloha Čierna zem, miesto výskumu v roku 1998; 3 - poloha Čierna zem skúmaná v roku 2008 a 2009: a - archeologicky preskúmaná plocha; $\mathrm{b}$ - situovanie eneolitických objektov na ploche výskumu.

objektov zvýšil o d’alších 96. Celkový počet doteraz preskúmaných objektov v polohe Čierna zem je teda 146. Okrem už známeho osídlenia z doby bronzovej, laténskej a rímskej sa počas výskumu v roku 2009 na lokalite prvýkrát podarilo doložit aj osídlenie skupiny Lažňany z prelomu staršieho a stredného eneolitu. Svedčí o tom dovedna sedem sídliskových objektov (90-96), na ktorých vyhodnotenie sme sa $\mathrm{v}$ tejto štúdii zamerali.

\section{OPIS NÁLEZOVÝCH SITUÁCIÍ A NÁLEZOV}

Sledovaná bola celá trasa líniovej stavby rekonštrukcie plynovodu od štátnej cesty Velké Kapušany Ruská až po štátnu hranicu s Ukrajinou, v dížke 20,271 km. Línia zemných prác so šírkou 20 m (vrátane ochranného pásma stavby) zasiahla praveké i chronologicky mladšie archeologické objekty v úseku dlhom 302 m (obr. 2: 3a). Eneolitické objekty sa nachádzali v severovýchodnej časti archeologicky skúmanej plochy (obr. 2: 3b). Na výseku plánu výskumu s vyobrazením detailu miesta výskytu objektov skupiny Lažňany je zrejmá ich koncentrácia do jedného väčšieho komplexu, ktorého súčastou boli jamy 90-96. S uvedeným komplexom s istotou súviseli aj kolové jamy 59 a 60. Ďalšie kolové jamy (57 a 58) vyskytujúce sa v okolí boli bez archeologických nálezov (obr. 3). 


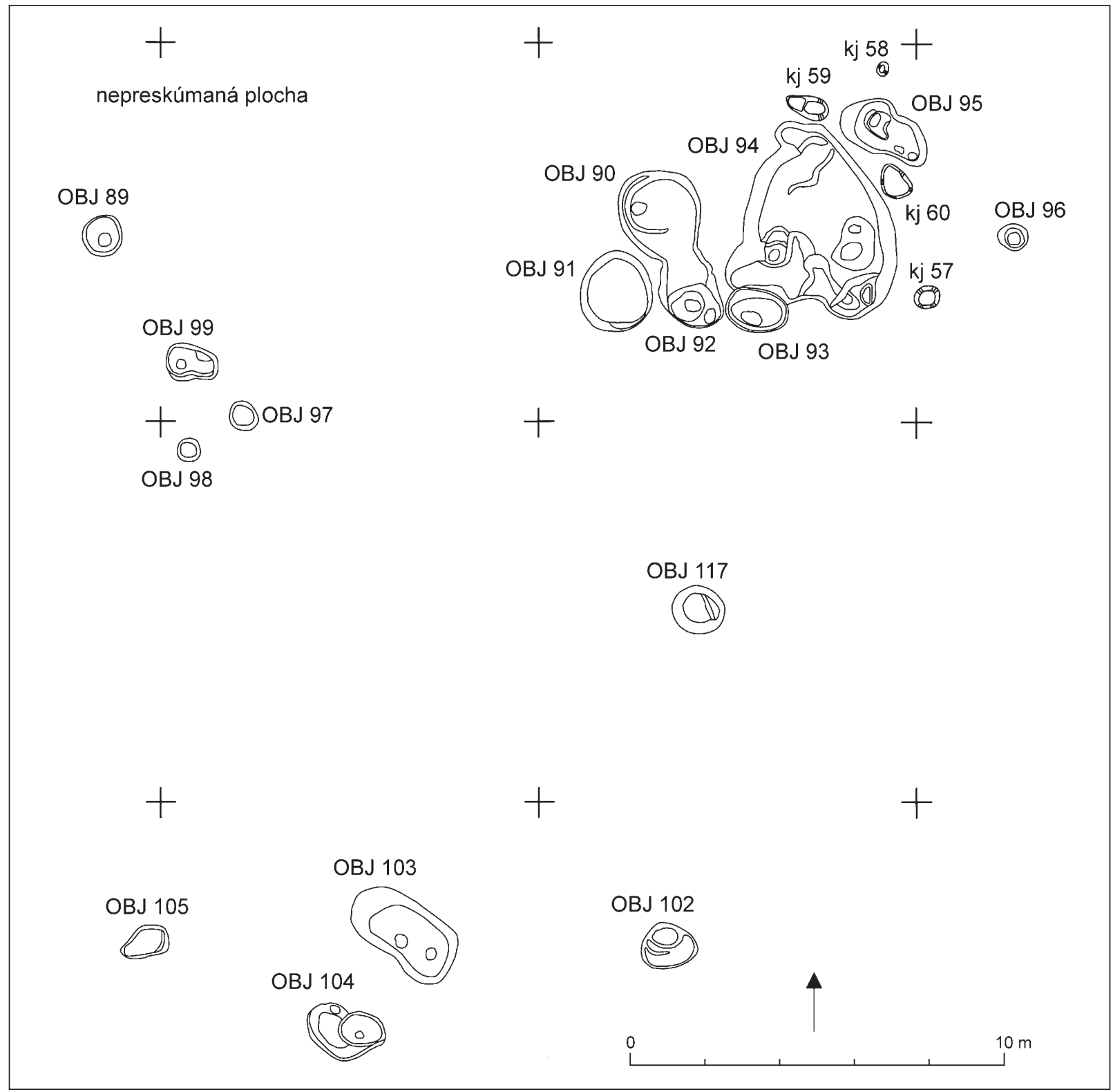

Obr. 3. Ruská, okr. Michalovce. Výsek situačného plánu výskumu s vyobrazením miesta výskumu eneolitických objektov (autori plánu L. Gačková, P. Šimčík).

\section{Objekt 90}

Jama oválneho pôdorysu s nerovnomerne zahíbeným dnom. Mala stupňovito upravenú západnú stenu. Jej južný okraj sa z dôvodu zásahu do objektu 92 nepodarilo s presnostou identifikovat. Výplň objektu tvorila tmavšia hlina hnedej farby, ktorá mala v spodnej časti svetlohnedú až žltú farbu. Rozmery: 2,28 x 2,08 m; hí. 0,54 m (tab. I).

\section{Opis nálezov}

1. Fragment pokrievky diskovitého tvaru s jedným zachovaným uškom na hrane plochého okraja. Povrch vyhladený. Makroskopický opis materiálu: jemne plavená hlina s drobnými kúskami šamotu. Farba: terakotová hnedá. Vrecko 1036 (tab. I: 1).

2. Črep z okraja tenkostennej nádoby s odsadeným hrdlom. Povrch hladený. Makroskopický opis materiálu: jemne plavená hlina s prímesou piesku. Farba: sivohnedá. Vrecko 1053 (tab. I: 2).

3. Fragment $\mathrm{z}$ hornej časti hrncovitej nádoby baňatého tvaru. V hornej časti sa zachovalo malé ucho presahujúce pôvodný okraj nádoby. Makroskopický opis materiálu: jemne plavená hlina s prímesou piesku a šamotu. Farba: tmavosivá. Vrecko 1004 (tab. I: 3). 
4. Pät fragmentov z hrubostennej hrncovitej nádoby s mierne vyhnutým hrdlom. Na jednom fragmente sa zachovalo mohutné ucho typu Scheibenhenkel s lalokovito formovaným výčnelkom a so zvislým stredovým rebrom. Makroskopický opis materiálu: hlina s kúskami šamotu. Farba: odtiene sivohnedej. Vrecko 1005 (tab. I: 4).

5. Dva črepy z tela jednej nádoby. Na jednom z nich sa nachádza výčnelok, ktorý je vytlačený z vnútornej strany. Povrch hladený. Makroskopický opis materiálu: jemne plavená hlina s prímesou piesku. Farba: odtiene tehlovohnedej. Vrecko 1036.

6. 15 kusov nevýrazných črepov z hrubostennej nádoby. Bez výzdoby. Makroskopický opis materiálu: jemne plavená hlina s prímesou piesku. Farba: odtiene hnedej. Vrecko 1036.

7. Štyri črepy z dna jednej hrubostennej nádoby. Makroskopický opis materiálu: jemne plavená hlina s prímesou piesku. Farba: terakotová hnedá, v profile keramická hmota tmavosivá. Vrecko 1036.

8. Fragment hrubostennej hrncovitej nádoby s uchom, ktoré je zdobené zvislým stredovým rebrom. ${ }^{4}$ Makroskopický opis materiálu: jemne plavená hlina s prímesou šamotu. Farba: sivá. Vrecko 1036.

9. Sedem črepov z tela jednej nádoby. Bez výzdoby. Makroskopický opis materiálu: jemne plavená hlina s prímesou piesku. Farba: odtiene hnedej. Vrecko 1049.

10. Pät črepov z hornej časti nádoby baňatého tvaru so zachovaným uchom pri okraji. Makroskopický opis materiálu: jemne plavená hlina s prímesou piesku. Farba: odtiene tmavohnedej. Vrecko 1049.

11. Neprofilovaný črep z okraja nádoby. Bez výzdoby. Makroskopický opis materiálu: jemne plavená hlina s prímesou piesku. Farba: terakotová hnedá. Vrecko 1004.

12. Črep z tela nádoby zdobený plným oválnym plastickým výčnelkom. Makroskopický opis materiálu: jemne plavená hlina s prímesou šamotu. Farba: svetlohnedá. Vrecko 1004.

13. Črep z okraja tenkostennej misy baňatého tvaru. Makroskopický opis materiálu: jemne plavená hlina s prímesou piesku. Farba: svetlosivá. Vrecko 1004.

14. Zlomok z aplikovanej plastickej lišty. Makroskopický opis materiálu: jemne plavená hlina. Farba: sivá. Vrecko 1004.

15. Črep z rozhrania dna a tela nádoby. Bez výzdoby. Makroskopický opis materiálu: jemne plavená hlina s prímesou piesku. Farba: hnedosivá. Vrecko 1053.

16. Črep z tela nádoby so zachovaným lomom po uchu, prípadne plastickom výčnelku. Makroskopický opis materiálu: jemne plavená hlina s prímesou piesku. Farba: hnedá. Vrecko 1053.

17. Črep z rozhrania tela a dna nádoby. Dno neodsadené. Makroskopický opis materiálu: jemne plavená hlina s prímesou piesku. Farba: hnedá. Vrecko 1053.

18. Dva črepy z hrubostenných nádob. Bez výzdoby. Makroskopický opis materiálu: jemne plavená hlina s prímesou piesku. Farba: odtiene hnedej. Vrecká 1036 a 1049.

19. 82 črepov z tiel nádob. Bez výzdoby. Makroskopický opis materiálu: jemne plavená hlina s prímesou piesku. Farba: odtiene hnedej až hnedosivej. Vrecká 0993, 1004, 1024, 1038 a 1053.

20. Drobný predmet. Škrabadlo. Materiál: kameň. Surovina: neurčená. Vrecko 1006.

21. Kúsky mazanice. Počet: neuvedený. Vrecká 1037 a 1039.

\section{Objekt 91}

Jama oválneho pôdorysu s mierne šikmými stenami a takmer rovným dnom. Nachádzala sa juhozápadne od objektu 90 a severozápadne od objektu 92. Výplň objektu tvorila hlina hnedej až svetlohnedej farby. Rozmery: 2,08 x 1,80 m; hí. 0,53 m (tab. II).

\section{Opis nálezov}

1. Z časti zachované ucho $\mathrm{z}$ tela hrubostennej nádoby. Makroskopický opis materiálu: hlina s prímesou piesku. Farba: sivohnedá. Vrecko 1007 (tab. II: 1).

2. Črep z tela tenkostennej nádobky baňatého tvaru s malým vertikálne perforovaným uškom. Makroskopický opis materiálu: jemne plavená hlina s prímesou piesku. Farba: sivohnedá. Vrecko 1040 (tab. II: 2).

3. Dva črepy z dien nádob. Makroskopický opis materiálu: jemne plavená hlina s prímesou piesku a šamotu. Farba: odtiene tmavosivej. Vrecko 1040.

4. Črep z rozhrania tela a dna nádoby. Bez výzdoby. Makroskopický opis materiálu: jemne plavená hlina s prímesou piesku. Farba: hnedá. Vrecko 0994.

5. 19 črepov z tiel nádob. Bez výzdoby. Makroskopický opis materiálu: jemne plavená hlina s prímesou piesku. Farba: odtiene hnedej až hnedosivej. Vrecká 0990, 0994, 1007, 1040 a 1054.

6. Zlomok obrúseného kameňa. Surovina: pieskovec. Vrecko 1040 (tab. I: 3).

7. Drobný predmet. Sekundárne prepálený úštep. Materiál: kameň. Surovina: neurčená. Vrecko 1041.

8. Sedem kusov mazanice. Vrecko 1042.

\footnotetext{
${ }^{4}$ Nebol súčastou nádoby, ktorej fragmenty sú uložené vo vrecku 1005 (pozri opis 4).
} 


\section{Objekt 92}

Jama nepravidelného oválneho pôdorysu s asymetrickými stenami a nerovnomerne zahĺbeným dnom. V severnej časti zasahovala do objektu 90 . Výplň objektu v hornej tretine tvorila hlina hnedej farby. Pod ňou sa nachádzala tmavšia hlina s obsahom uhlíkov. Spodná časṫ výplne jamy mala svetlohnedú farbu. Rozmery: 1,90 x 1,50 m; hí. 0,66 m (tab. III).

\section{Opis nálezov}

1. Fragment z rozhrania hrdla a tela tenkostennej nádoby s kónickým výrazne odsadeným hrdlom a zaobleným telom. Bez výzdoby. Makroskopický opis materiálu: jemne plavená hlina s prímesou piesku. Farba: sivohnedá. Vrecko 1009 (tab. III: 1).

2. Fragment amforovitej nádoby s kónickým hrdlom a naznačeným rozšíreným telom. Na rozhraní hrdla a tela sa zachovalo malé uško s horizontálnym otvorom. Makroskopický opis materiálu: jemne plavená hlina s prímesou piesku. Farba: sivohnedá. Vrecko 1009 (tab. III: 2).

3. Tri črepy z jednej amforovitej nádoby, ktorá mala výrazne odsadené hrdlo. Na rozhraní hrdla a tela sa zachovalo ucho typu Scheibenhenkel s lalokovito formovaným výčnelkom. Na pleciach sa nachádzajú tri malé výčnelky oválneho tvaru. Makroskopický opis materiálu: jemne plavená hlina s prímesou piesku. Farba: odtiene sivohnedej. Vrecko 1056 (tab. III: 3).

4. Črepy z hrncovitej nádoby s odsadeným hrdlom. Z hrdla nad okraj presahujú dve pásikové uchá typu Scheibenhenkel s lalokovito formovanými výčnelkami. Pod hrdlom je naznačená tenká ryha. Makroskopický opis materiálu: jemne plavená hlina s prímesou piesku. Farba: odtiene svetlohnedej. Vrecko 1013 (tab. III: 4).

5. Zlomok z hornej časti nádoby. Pri okraji sa nachádza oválne ucho s horizontálnym otvorom. Makroskopický opis materiálu: jemne plavená hlina s prímesou piesku a šamotu. Farba: hnedá. Vrecko 1009 (tab. IV: 1).

6. Črep z okraja nádoby s malým oválnym uškom. Makroskopický opis materiálu: jemne plavená hlina. Farba: terakotová hnedá. Vrecko 1055 (tab. IV: 2).

7. Plochý črep z okraja hranatej nádoby. Nad okraj prečnieva malé horizontálne prevŕtané uško. Makroskopický opis materiálu: jemne plavená hlina s prímesou piesku. Farba: hnedosivá. Vrecko 0997 (tab. IV: 3).

8. Takmer úplne zachované dno z nádoby neznámeho tvaru. Priemer 6,2 cm. Makroskopický opis materiálu: jemne plavená hlina s prímesou piesku. Farba: hnedosivá. Vrecko 0997 (tab. IV: 4).

9. Črep z tela nádoby s uchom, ktoré má horizontálny otvor. Makroskopický opis materiálu: jemne plavená hlina s prímesou piesku. Farba: sivá. Vrecko 1056 (tab. IV: 5).

10. Črep z hrdla nádoby, ktorý je na okraji pretláčaný nepravidelnými jamkami. Makroskopický opis materiálu: jemne plavená hlina s prímesou piesku. Farba: hnedá. Vrecko 0997 (tab. IV: 6).

11. Črep z rozhrania hrdla a tela tenkostennej nádoby menších rozmerov s miniatúrnym, zaobleným a horizontálne perforovaným výčnelkom. Makroskopický opis materiálu: jemne plavená hlina s prímesou piesku. Farba: sivohnedá. Vrecko 1009 (tab. IV: 7).

12. Črep z hrdla nádoby. Okraj zdobia asymetrické vtlačené jamky. Makroskopický opis materiálu: jemne plavená hlina s prímesou piesku. Farba: sivá. Vrecko 0996 (tab. IV: 8).

13. Ćrep z hrdla nádoby. Okraj zdobia nevýrazné vtlačené jamky nepravidelného tvaru. Makroskopický opis materiálu: hlina s prímesou piesku. Farba: svetlohnedá. Vrecko 1008 (tab. IV: 9).

14. Črep z tenkostennej nádoby s výrazne odsadeným hrdlom. Bez výzdoby. Makroskopický opis materiálu: jemne plavená hlina. Farba: sivá. Vrecko 1055 (tab. IV: 10).

15. Črep z rozhrania hrdla a tela nádoby. Na vydutine sa nachádza vyhladený plastický výčnelok. Makroskopický opis materiálu: hlina s prímesou piesku. Farba: hnedá. Vrecko 1065 (tab. IV: 11).

16. Črep z rozhrania hrdla a tela nádoby s miniatúrnym, zaobleným a horizontálne perforovaným výčnelkom. Makroskopický opis materiálu: jemne plavená hlina s prímesou piesku. Farba: hnedá. Vrecko 1009 (tab. IV: 12).

17. Črep z hornej časti nádoby s mierne vyhnutým hrdlom. Bez výzdoby. Makroskopický opis materiálu: jemne plavená hlina s prímesou piesku. Farba: svetlohnedá. Vrecko 1008 (tab. IV: 13).

18. Fragment hlineného predmetu naznačeného kruhového tvaru s plochým a rovným okrajom. Predmet je v mieste stredového otvoru z jednej strany plochý a z druhej rozšírený. Interpretácia nálezu: koliesko (?). Makroskopický opis materiálu: jemne plavená hlina s prímesou piesku. Farba: sivá. Vrecko 0996 (tab. IV: 14).

19. Črep z hornej časti nádoby. Na okraji sa z vonkajšej strany nachádzajú jamky nepravidelného tvaru. Makroskopický opis materiálu: jemne plavená hlina s prímesou piesku. Farba: sivohnedá. Vrecko 0996 (tab. IV: 15).

20. Črep z rozhrania hrdla a tela nádoby. Bez výzdoby. Makroskopický opis materiálu: jemne plavená hlina s prímesou piesku. Farba: sivohnedá. Vrecko 1012 (tab. IV: 16).

21. Črep z hornej časti nádoby s výrazne odsadeným hrdlom. Bez výzdoby. Makroskopický opis materiálu: jemne plavená hlina s prímesou piesku. Farba: sivohnedá. Vrecko 1057 (tab. IV: 17).

22. Črep z rozhrania hrdla a tela malej profilovanej nádoby s výrazne odsadeným hrdlom. Bez výzdoby. Makroskopický opis materiálu: jemne plavená hlina s prímesou piesku. Farba: sivohnedá. Vrecko 0995 (tab. IV: 18).

23. Črep z tela hrubostennej nádoby zdobený plastickými pretláčanými lištami. Makroskopický opis materiálu: hlina s prímesou piesku. Farba: svetlohnedá. Vrecko 0995 (tab. V: 1).

24. Ćrep z hornej časti nádoby. Bez výzdoby. Makroskopický opis materiálu: jemne plavená hlina s prímesou piesku. Farba: sivohnedá. Vrecko 1012 (tab. V: 2).

25. Črep z tela nádoby s člnkovitým vertikálne perforovaným uchom. Makroskopický opis materiálu: jemne plavená hlina s prímesou piesku. Farba: sivohnedá. Vrecko 1009 (tab. V: 3). 
26. Dva črepy z tela tej istej tenkostennej nádoby, ktoré majú z vnútornej do vonkajšej strany vytlačené vydutiny. Makroskopický opis materiálu: jemne plavená hlina. Farba: sivohnedá. Vrecko 1009 (tab. V: 4, 7).

27. Črep z rozhrania hrdla a tela nádoby so zachovaným lomom po ulomenom uchu, pod ktorým sa nachádza nevýrazný plastický výčnelok. Makroskopický opis materiálu: jemne plavená hlina s prímesou piesku. Farba: terakotová hnedá. Vrecko 1055 (tab. V: 5).

28. Črep z hornej časti tenkostennej nádoby. Bez výzdoby. Makroskopický opis materiálu: jemne plavená hlina s prímesou piesku. Farba: sivohnedá. Vrecko 1009 (tab. V: 6).

29. Črep z hornej časti nádoby s pretláčaným okrajom. Povrch zdrsnený. Makroskopický opis materiálu: hlina s prímesou šamotu. Farba: svetlohnedá. Vrecko 1065 (tab. V: 8).

30. Tri črepy z okrajov nádob. Makroskopický opis materiálu: jemne plavená hlina s prímesou piesku. Farba: odtiene hnedej. Vrecko 1009.

31. 12 črepov z dien nádob. Makroskopický opis materiálu: jemne plavená hlina s prímesou piesku. Farba: odtiene hnedej. Vrecká 0989, 0995, 0996, 1008, 1012, 1050 a 1055.

32. Črep z okraja tenkostennej nádoby. Bez výzdoby. Makroskopický opis materiálu: jemne plavená hlina s prímesou piesku. Farba: svetlohnedá. Vrecko 0989.

33. Neprofilovaný črep z okraja nádoby. Bez výzdoby. Makroskopický opis materiálu: jemne plavená hlina s prímesou piesku. Farba: sivohnedá. Vrecko 0995.

34. Črep z hrubostennej nádoby hrncovitého tvaru s mohutným plastickým výčnelkom. Makroskopický opis materiálu: hlina s prímesou piesku. Farba: svetlohnedá. Vrecko 0995.

35. Črep z okraja a časti tela nádoby. Bez výzdoby. Makroskopický opis materiálu: jemne plavená hlina s prímesou piesku. Farba: sivá. Vrecko 0996.

36. Črep z tela nádoby s plastickým výčnelkom oválneho tvaru. Makroskopický opis materiálu: jemne plavená hlina s prímesou piesku. Farba: hnedá. Vrecko 0996.

37. Dva zlomky z malého uška oblého tvaru. Makroskopický opis materiálu: jemne plavená hlina s prímesou piesku. Farba: hnedosivá. Vrecko 0997.

38. Tenkostenný črep z okraja nádoby. Bez výzdoby. Makroskopický opis materiálu: jemne plavená hlina s prímesou piesku. Farba: hnedá. Vrecko 0997.

39. Črep z hrubostennej nádoby s plastickým výčnelkom oválneho tvaru. Farba: hnedá. Vrecko 1008.

40. Črep z tela nádoby s tupým plastickým výčnelkom. Makroskopický opis materiálu: jemne plavená hlina s prímesou piesku. Farba: hnedá. Vrecko 1008.

41. 14 sekundárne prepálených črepov z jednej nádoby. Makroskopický opis materiálu: prepálená hlina. Farba: odtiene čiernej a sivočiernej. Vrecko 1010.

42. Črep z misy s vyhnutým okrajom. Bez výzdoby. Makroskopický opis materiálu: jemne plavená hlina s prímesou piesku. Farba: hnedá. Vrecko 1009.

43. Plastický výčnelok. Makroskopický opis materiálu: jemne plavená hlina s prímesou piesku. Farba: hnedá. Vrecko 1012.

44. 13 črepov z jednej nádoby. Bez výzdoby. Makroskopický opis materiálu: jemne plavená hlina s prímesou piesku. Farba: odtiene sivohnedej. Vrecko 1020.

45. Pät črepov. Bez výzdoby. Makroskopický opis materiálu: jemne plavená hlina s prímesou piesku. Farba: odtiene sivohnedej. Vrecko 1043.

46. 15 črepov z jednej nádoby. Bez výzdoby. Makroskopický opis materiálu: jemne plavená hlina s prímesou piesku. Farba: odtiene sivohnedej. Vrecko 1021.

47. Črep z okraja nádoby. Bez výzdoby. Makroskopický opis materiálu: jemne plavená hlina s prímesou piesku. Farba: sivá. Vrecko 1044.

48. Črep s plastickým výčnelkom a zdrsneným povrchom. Makroskopický opis materiálu: jemne plavená hlina. Farba: hnedosivá. Vrecko 1055.

49. Črep z okraja širšej neprofilovanej nádoby. Bez výzdoby. Makroskopický opis materiálu: jemne plavená hlina s prímesou šamotu. Farba: sivohnedá. Vrecko 1055.

50. Črep z nádoby s vyšším výrazne odsadeným hrdlom. Bez výzdoby. Makroskopický opis materiálu: jemne plavená hlina. Farba: sivohnedá. Vrecko 1055.

51. Črep z okraja hrubostennej nádoby. Makroskopický opis materiálu: jemne plavená hlina s prímesou šamotu. Farba: hnedá. Vrecko 1056.

52. 15 črepov z hrubostenných nádob. Bez výzdoby. Makroskopický opis materiálu: jemne plavená hlina s prímesou piesku. Farba: odtiene hnedej a sivej. Vrecko 1057.

53. Črep z rozhrania dna a tela hrubostennej nádoby. Makroskopický opis materiálu: hlina s prímesou piesku. Farba: terakotová hnedá. Vrecko 1065.

54. Črep z okraja tenkostennej nádoby s pretláčaným okrajom. Makroskopický opis materiálu: hlina s prímesou šamotu. Farba: svetlohnedá. Vrecko 1065.

55. 236 črepov z tiel nádob. Bez výzdoby. Makroskopický opis materiálu: jemne plavená hlina s prímesou piesku.

Farba: odtiene hnedej a sivej. Vrecká 0989, 0995, 0996, 1008, 1009, 1012, 1044, 1046, 1050, 1055, 1058 a 1065.

56. Drobné predmety. Fragmenty čepelí. Surovina: obsidián. Počet: neuvedený. Vrecko 1011.

57. Kúsky mazanice. Počet: neuvedený. Vrecká 1022, 1045, 1059 a 1066. 


\section{Objekt 93}

Jama elipsovitého tvaru s nerovnými zošikmenými stenami a nepravidelným dnom. Situovaná bola východne od objektu 92 a svojim severným až severovýchodným okrajom zasahovala do objektu 94. Výplň objektu tvorila hlina tmavohnedej farby s prímesou mazanice a drobných uhlíkov. Rozmery: 1,60 x 1,10 m; hí. 0,60 m (tab. V).

\section{Opis nálezov}

1. Plastický výčnelok z hrubostennej nádoby. Makroskopický opis materiálu: plavená hlina. Farba: svetlohnedá. Vrecko 1025 (tab. V: 9).

2. Črep z okraja nádoby s oválnym výčnelkom. Makroskopický opis materiálu: plavená hlina. Farba: svetlohnedá. Vrecko 1025 (tab. V: 10).

3. Dva črepy s pretláčanými okrajmi z horných častí nádob. Makroskopický opis materiálu: jemne plavená hlina. Farba: odtiene sivohnedej. Vrecko 1025 (tab. V: 11, 12).

4. Črep z hornej časti tenkostennej nádoby s pretláčaným okrajom a malým horizontálne perforovaným uškom. Makroskopický opis materiálu: plavená hlina s prímesou šamotu. Farba: sivohnedá. Vrecko 1025 (tab. V: 13).

5. Črep z okraja tenkostennej nádoby. Bez výzdoby. Makroskopický opis materiálu: jemne plavená hlina. Farba: sivohnedá. Vrecko 1025 (tab. V: 14).

6. Črep z tela nádoby so zdvojeným plastickým výčnelkom. Makroskopický opis materiálu: plavená hlina s prímesou šamotu. Farba: sivohnedá. Vrecko 1025 (tab. V: 15).

7. Dva črepy z dolnej časti tela štvorhranného kalicha. Jedna strana má plasticky pretláčanú hranu. Z vnútornej strany, na mieste prelomenia stien, je vyhĺbený žliabok. Makroskopický opis materiálu: jemne plavená hlina. Farba: odtiene sivej. Vrecko 1025 (tab. V: 16).

8. Dva črepy zo spodnej časti nádob. Makroskopický opis materiálu: hlina s prímesou šamotu. Farba: odtiene sivohnedej. Vrecko 1025.

9. Spodná čast' nádoby s odsadeným dnom. Makroskopický opis materiálu: hlina s prímesou šamotu. Farba: sivohnedá. Vrecko 1025.

10. Pät črepov z tela tenkostennej nádoby. Bez výzdoby. Makroskopický opis materiálu: plavená hlina s prímesou piesku. Farba: odtiene sivej. Vrecko 1025.

11. Črep z okraja tenkostennej nádoby. Bez výzdoby. Makroskopický opis materiálu: jemne plavená hlina. Farba: hnedosivá. Vrecko 1025.

12. 17 črepov z tiel hrubostenných nádob. Bez výzdoby. Makroskopický opis materiálu: plavená hlina s prímesou šamotu. Farba: odtiene hnedej a sivej. Vrecká 0998 a 1023.

13. 30 črepov z tiel nádob. Bez výzdoby. Makroskopický opis materiálu: plavená hlina s prímesou piesku. Farba: odtiene hnedej a sivej. Vrecko 1025.

14. Opracovaný kameň. Materiál: kameň. Surovina: neurčená. Vrecko 1026.

15. Drobné predmety. Úštepy. Materiál: kameň. Surovina: obsidián. Počet: neuvedený. Vrecko 1027.

16. Otíkač. Materiál: kameň. Surovina: Neurčená. Vrecko 1026.

17. 17 kusov mazanice. Vrecko 1028.

\section{Objekt 94}

Rozmerná jama asymetrického tvaru. V jej najbližšom okolí boli vyhíbené satelitné objekty 90, 92, 93, 95 a 96, ako aj kolové jamy 57 až 60. Dno objektu klesalo zo severnej strany na južnú, kde sa rozširoval aj jeho pôdorys. Spodná čast’ jamy bola rozčlenená na viacero menších preliačin až prehlbenín. Pozdĺž jej západnej steny sa nachádzal žlab, ktorý ústil do najhlbšej dvojúrovňovej priehlbne oválneho tvaru s rozmermi 1 x 0,80 m. V juhovýchodnej časti sa vyskytovala druhá väčšia priehlbeň, ktorá z časti zasahovala pod juhovýchodný okraj jamy. Jej rozmery dosahovali 1,63 a $1 \mathrm{~m}$. Severne od nej bola rozpoznaná tretia priehlbeň nepravidelného tvaru. Rozmery celého objektu: 5,34 x 4,40 m; hí. 1,05 m (tab. VI: 6).

\section{Opis nálezov}

1. Tri črepy z hornej časti nádob. Na každom z nich sa pri okraji zachovalo menšie horizontálne perforované uško. Makroskopický opis materiálu: jemne plavená hlina s prímesou piesku. Farba: odtiene hnedej. Vrecká 1013 a 1099 (tab. VI: $1,2,8)$.

2. Tri črepy z okraja, tela a dna štvorhranného kalicha. Jeho výzdoba pozostávala z nepravidelných jamiek vhĺbených pozdĺž zvislých hrán zalomených stien. Nad ústie kalicha v mieste zalomenia stien pravdepodobne prečnievali štyri lalokovité výčnelky, z ktorých sa zachoval len jeden. Makroskopický opis materiálu: jemne plavená hlina. Farba: odtiene sivohnedej. Vrecká 1091, 1095 a 1106 (tab. VI: 3, 4, 6).

3. Črep z rozhrania tela a hrdla misky. Pod hrdlom je naznačený výrazný zlom. Na tele sa zachovalo malé horizontálne perforované uško. Makroskopický opis materiálu: hlina s prímesou piesku. Farba: svetlohnedá. Vrecko 1075 (tab. VI: 5).

4. Zlomok z hornej časti tela nádoby s mohutným člnkovitým uchom. Makroskopický opis materiálu: hlina s prímesou piesku. Farba: svetlohnedá. Vrecko 1075 (tab. VI: 7).

5. Fragment z tela hrubostennej nádoby s mohutným pásikovým uchom. Makroskopický opis materiálu: hlina s prímesou piesku. Farba: terakotová hnedá. Vrecko 1091 (tab. VI: 9). 
6. Fragment $\mathrm{z}$ hornej časti amforovitej nádoby alebo vázy s kónickým hrdlom. Bez výzdoby. Telo sa nezachovalo. Makroskopický opis materiálu: hlina s prímesou piesku. Farba: hnedá. Vrecko neuvedené (tab. VII: 1).

7. Fragment $\mathrm{z}$ hornej časti nádoby s rovným hrdlom. Na jeho okraji sa nachádza výzdoba v podobe vtlačených jamiek. Makroskopický opis materiálu: hlina s prímesou piesku. Farba: svetlohnedá. Vrecko neuvedené (tab. VII: 2).

8. Fragment misy s cylindrickým hrdlom, odsadeným baňatým telom a rovným dnom. Pod rozhraním hrdla a tela sa z nádoby zachovalo jedno uško s horizontálnym otvorom. Makroskopický opis materiálu: hlina s prímesou piesku. Farba: svetlohnedá. Vrecko 0085 (tab. VII: 3).

9. Fragment misy s mierne roztvoreným hrdlom a baňatým telom. Jej dno sa nezachovalo. Pod rozhraním hrdla a tela je umiestnené malé vertikálne perforované uško typu Scheibenhenkel s lalokovito formovaným výčnelkom. Makroskopický opis materiálu: hlina s prímesou piesku. Farba: sivá. Vrecko 1009 (tab. VII: 4).

10. Črep z misy s mierne dovnútra vtiahnutým okrajom. Bez výzdoby. Makroskopický opis materiálu: hlina. Farba: hnedá. Vrecko 1075. 1075.

11. Črep z misy s rovným okrajom. Bez výzdoby. Makroskopický opis materiálu: hlina. Farba: sivohnedá. Vrecko

12. Črep z tela nádoby s hrubým plastickým výčnelkom. Makroskopický opis materiálu: hlina. Farba: svetlohnedá. Vrecko 1075. 1075.

13. Črep z tela misy baňatého tvaru. Bez výzdoby. Makroskopický opis materiálu: hlina. Farba: svetlohnedá. Vrecko

14. Tri črepy z tiel nádob s plastickým výčnelkom. Makroskopický opis materiálu: hlina. Farba: odtiene svetlohnedej. Vrecko 1075.

15. Črep z misy s vyhnutým okrajom. Makroskopický opis materiálu: hlina. Farba: svetlohnedá. Vrecko 1075.

16. Dva črepy z misy, ktorá má slabo naznačenou ryhou zvýraznené rozhranie hrdla a tela. Makroskopický opis materiálu: hlina. Farba: odtiene svetlohnedej. Vrecko 1075.

17. Črep z okraja neprofilovanej misy. Makroskopický opis materiálu: jemne plavená hlina. Farba: svetlohnedá. Vrecko 1075.

18. Črep so zachovaným uchom. Makroskopický opis materiálu: hlina. Farba: svetlohnedá. Vrecko 1075.

19. Črep z nádoby s uškom vychádzajúcim z okraja. Makroskopický opis materiálu: hlina. Farba: svetlohnedá. Vrecko 36.

20. Črep z väčšej nádoby s člnkovitým uchom. Makroskopický opis materiálu: hlina s prímesou šamotu. Farba: sivá. Vrecko 1082.

21. Hrubostenný črep z tela nádoby s ulomeným uchom. Makroskopický opis materiálu: hlina s prímesou šamotu. Farba: terakotová hnedá. Vrecko 1082.

22. Črep z tela nádoby s plastickým výčnelkom. Makroskopický opis materiálu: hlina s prímesou piesku. Farba: terakotová hnedá. Vrecko 1085.

23. Črep z okraja hrncovitej nádoby. Nad okraj prečnieva ucho s horizontálnym otvorom. Makroskopický opis materiálu: hlina s prímesou piesku. Farba: terakotová hnedá. Vrecko 1085.

24. Štyri črepy z jednej nádoby s neprofilovaným okrajom. Makroskopický opis materiálu: hlina s prímesou piesku. Farba: odtiene hnedej. Vrecko 1113.

25. Zlomok ucha z hrubostennej nádoby. Makroskopický opis materiálu: hlina s prímesou piesku. Farba: sivá. Vrecko 1113

26. Črep z okraja nádoby s oválnym plastickým výčnelkom. Makroskopický opis materiálu: hlina s prímesou piesku. Farba: hnedá. Vrecko 1099.

27. Črep z tela nádoby s oválnym plastickým výčnelkom. Makroskopický opis materiálu: hlina s prímesou piesku. Farba: terakotová hnedá. Vrecko 1099.

28. Črep z okraja nádoby. Bez výzdoby. Makroskopický opis materiálu: hlina s prímesou piesku. Farba: svetlohnedá. Vrecko 1121.

29. Zlomok hrubostenného ucha. Makroskopický opis materiálu: hlina s prímesou piesku. Farba: svetlohnedá. Vrecko 1121.

30. Črep z tela nádoby s ulomeným uchom. Makroskopický opis materiálu: hlina s prímesou piesku. Farba: terakotová hnedá. Vrecko 1125.

31. Zlomok malého ucha. Makroskopický opis materiálu: hlina s prímesou piesku. Farba: sivohnedá. Vrecko 1125.

32. Zlomok člnkovitého ucha z hrubostennej nádoby. Makroskopický opis materiálu: hlina s prímesou piesku. Farba: terakotová hnedá. Vrecko 1125.

33. Neprofilovaný črep z okraja tenkostennej nádoby. Makroskopický opis materiálu: hlina s prímesou piesku. Farba: terakotová hnedá. Vrecko 1088.

34. Črep z rozhrania hrdla a tela hrubostennej nádoby. Bez výzdoby. Makroskopický opis materiálu: hlina s prímesou piesku. Farba: tehlová. Vrecko 1088.

35. Črep z rozhrania hrdla a tela stredne hrubostennej nádoby. Bez výzdoby. Makroskopický opis materiálu: hlina s prímesou piesku. Farba: sivohnedá. Vrecko 1088.

36. Tri črepy z okrajov nádob. Bez výzdoby. Makroskopický opis materiálu: hlina s prímesou piesku. Farba: odtiene hnedej. Vrecko 1095.

37. Črep z okraja misy s výčnelkom. Makroskopický opis materiálu: hlina s prímesou piesku. Farba: svetlohnedá. Vrecko 1095.

38. Zlomky dvoch úch z hrubostenných nádob. Bez výzdoby. Makroskopický opis materiálu: hlina s prímesou piesku. Farba: odtiene hnedej. Vrecko 1095. 
39. Črep z okraja misy. Bez výzdoby. Makroskopický opis materiálu: hlina s prímesou piesku. Farba: sivá. Vrecko 1095.

40. Črep z hornej časti nádoby s vyvýšeným lalokovito vytiahnutým okrajom. Makroskopický opis materiálu: hlina s prímesou piesku. Farba: sivá. Vrecko 1095.

41. Dva črepy z hornej časti nádob s pretláčaným okrajom. Makroskopický opis materiálu: hlina s prímesou piesku. Farba: odtiene hnedej. Vrecko 1097.

42. Zlomky dvoch úch z hrubostenných nádob. Makroskopický opis materiálu: hlina. Farba: tehlová. Vrecko 1104. 1104.

43. Črep z okraja nádoby. Bez výzdoby. Makroskopický opis materiálu: hlina s prímesou piesku. Farba: sivá. Vrecko

44. Črep z tela nádoby s plastickým výčnelkom. Makroskopický opis materiálu: hlina s prímesou piesku. Farba: terakotová hnedá. Vrecko 1104.

45. 19 črepov z dien nádob. Makroskopický opis materiálu: hlina s prímesou šamotu. Farba: odtiene hnedej a sivej. Vrecká 1075, 1085, 1091, 1112, 1121 a 1125.

46. 434 črepov z tiel nádob. Bez výzdoby. Makroskopický opis materiálu: hlina s prímesou šamotu. Farba: odtiene hnedej a sivej. Vrecká 1075, 1082, 1085, 1088, 1095, 1097, 1103, 1104, 1112-1114, 1117, 1121, 1125, 1129 a 1130.

47. Drobný predmet. Úštep. Materiál: kameň. Surovina: neurčená. Vrecko 1086.

48. Drobný predmet. Úštep. Materiál: kameň. Surovina: neurčená. Vrecko 1101.

49. Drobný predmet. Úštep. Materiál: kameň. Surovina: neurčená. Vrecko 1116.

50. Drobný predmet. Úštep. Materiál: kameň. Surovina: neurčená. Vrecko 1131.

51. Drobné predmety. Úštepy. Materiál: kameň. Surovina: obsidián. Počet: neuvedený. Vrecko 1092.

52. Drobný predmet. Čepel. Materiál: kameň. Surovina: rohovec. Vrecko 1115.

53. Fragment zrnotierky. Materiál: kameň. Surovina: neurčená. Vrecko 1127.

54. Hluza z obsidiánu. Vrecko 1093.

55. Kúsky mazanice. Počet: neuvedený. Vrecká 1079, 1102 a 1128.

56. Zle zachované zvieracie kosti. Bez uvedenia počtu.

\section{Objekt 95}

Jama asymetrického pôdorysu s nepravidelne zahĺbeným dnom a stupňovitými stenami. Situovaná bola severovýchodne od objektu 94. Na dne objektu sa nachádzali tri priehlbne. Prvá z nich, rozpoznaná vo východnej časti jamy, dosahovala priemer $0,25 \mathrm{~m}$. Západne od nej bola situovaná druhá priehlbeň takmer rovnakých rozmerov. Najväčšie zahĺbenie sa zistilo v severozápadnej časti objektu. Jeho rozmery dosahovali $0,70 \times 0,58 \mathrm{~m}$. Výplň objektu tvorila hlina hnedej farby s obsahom ojedinelých črepov. Celkové rozmery objektu: 2,44 x 1,41 m, hí. 0,35 m (tab. II).

\section{Opis nálezov}

1. Tri črepy z tiel nádob. Bez výzdoby. Makroskopický opis materiálu: hlina s prímesou piesku a šamotu. Farba: odtiene hnedej. Vrecko 1060.

\section{Objekt 96}

Jama bola výraznejšie porušená pri znižovaní terénu mechanizmom. Jej zachovaný pôdorys naznačoval oválny tvar. Objekt mal zošikmené steny a zaoblené dno. Jeho výplň tvorila hlina hnedej farby s obsahom ojedinelých črepov. Rozmery: 0,78 x 0,70 m, hí. 0,38 m (tab. II).

\section{Opis nálezov}

1. 13 črepov z tiel nádob. Bez výzdoby. Makroskopický opis materiálu: hlina s prímesou piesku a šamotu. Farba: odtiene hnedej. Vrecká 1014 a 1029.

2. Črep z tela nádoby s malým plastickým výčnelkom. Makroskopický opis materiálu: hlina s prímesou piesku a šamotu. Farba: hnedosivá. Vrecko 1014.

\section{Kolová jama 57}

Situovaná bola juhovýchodne od objektu 94. Opis kolovej jamy nebol v dokumentácii zaznamenaný. Bez nálezov (obr. 3).

\section{Kolová jama 58}

Situovaná bola severne od objektu 95. Opis kolovej jamy nebol v dokumentácii zaznamenaný. Bez nálezov (obr. 3). 


\section{Kolová jama 59}

Situovaná bola severne od objektu 94 a západne od objektu 95. V dokumentácii bol zaznamenaný len údaj o híbke kolovej jamy: 0,30 m (obr. 3).

\section{Opis nálezov}

1. Štyri črepy z dna jednej nádoby. Bez výzdoby. Makroskopický opis materiálu: hlina s prímesou piesku a šamotu. Farba: hnedosivá. Vrecko 1118.

\section{Kolová jama 60}

Situovaná bola južne od objektu 95. V dokumentácii bol zaznamenaný len údaj o híbke kolovej jamy: 0,20 m (obr. 3).

\section{Opis nálezov}

1. Tri črepy z tiel nádob. Bez výzdoby. Makroskopický opis materiálu: hlina s prímesou piesku a šamotu. Farba: odtiene hnedej. Vrecko 1119.

\section{ANALÝZA ARCHEOLOGICKÝCH OBJEKTOV}

Opísané sídliskové jamy z eneolitu tvorili len čast’ z celkovej plochy sídliska skupiny Lažňany. Z tejto etapy osídlenia polohy Čierna zem sa na rozlohe menšej ako $60 \mathrm{~m}^{2}$ podarilo rozpoznat zoskupenie siedmich sídliskových jám a dvoch kolových jám. Menšie objekty boli vyhíbené v okolí centrálneho a zároveň aj najrozmernejšieho objektu 94, dokonca niektoré doň aj priamo zasahovali. Severne, severovýchodne a juhovýchodne od pôdorysu objektu 94 sa vyskytovali štyri kolové jamy, z ktorých len dve (59 a 60) obsahovali materiál skupiny Lažňany. Ďalšie dve kolové jamy (57 a 58) boli bez nálezov. Sídliskové objekty mali nepravidelne oválny, elipsovitý a asymetrický pôdorys a stupňovito až nerovnomerne vyhĺbené steny. $V$ ich spodných častiach sa nachádzali viaceré preliačiny. Výnimkou bol len objekt 91 s oválnym pôdorysom, mierne zošikmenými stenami a takmer rovným dnom. Zachované rozmery menších jám, pri nezohl'adnení vel'kosti poškodeného objektu 96, dosahovali dížku od 1,60 do 2,44 m, šírku od 1,10 do 2,08 m a híbku od 0,35 do 0,66 m. Centrálny objekt mal rozmery 5,34 x 2,44 m s híbkou $1,05 \mathrm{~m}$.

Na porovnanie nálezových situácii z Ruskej s d’alšími objektmi skupiny Lažňany z Košickej kotliny, Šarišského Podolia a Východoslovenskej nížiny máme k dispozícii len málo výpovedné zdroje. Z okolia strednej Torysy k súhrnne piatim objektom z L’ubotíc, miestnej časti Šarišské lúky ${ }^{5}$ (Šiška 1976, 92-94) vrátane Ostrovian (Lamiová-Schmiedlová 1964, Šiška 1964, 74), pribudli nedávno dva, resp. tri sídliskové objekty v obci Dulová Ves. ${ }^{6} \mathrm{Z}$ ned’alekého katastra Vel'kého Sariša už desatročia registrujeme len bezobsažnú zmienku o existencii početných kultúrnych jám, ktoré sa spomínajú v súvislosti s obhliadkou ryhy pre vodovodné potrubie (Budinský-Krička 1964, 99). Ďalšiu lokalitu v Prešove na Pavlovičovom námestí evidujeme len vzhladom na výskyt zlomkov keramiky (Budinský-Krička 1964, obr. 12). Na Východoslovenskej nížine bola keramika podobného rázu rozpoznaná na sídlisku v Lúčkach založenom ned’aleko známeho žiarového pohrebiska v Malých Zalužiciach-Lažňanoch (Budinský-Krička 1961a, 42; 1961b, 295; 1961c, 66, 67; 1963, 630-686; 1964, 100, 104; Šiška 1972a, 108-110). Z regiónu dolného Zemplína sa sídliskové polohy bez bližších údajov uvádzajú aj z Vel'kých Raškoviec a Oborína (Budinský-Krička 1961a, 42; 1964, 100, 104). Z centra Košickej kotliny sme donedávna poznali len jedno sídlisko v Košiciach, v polohe Barca-Svetlá IV, kde L. Bánesz odkryl dná troch vel’mi zle rozpoznatelných sídliskových jám (Šiška 1970, 29-31, obr. 1; 2). Štyri sídliskové jamy boli preskúmané aj v Bidovciach. Najväčšia z nich dosahovala rozmery 4 × 3 m (Hreha 2016, 100). Podrobnejšie údaje o tomto, ani o d’alších troch objektoch neboli zverejnené. Z Košickej kotliny okrem spomínaných sídliskových polôh skupiny Lažňany evidujeme aj dve birituálne pohrebiská: jedno v Šebastovciach, v polohe Lapiše (Šiška 1970, 31-35; 1972a, 110-122), druhé v Košiciach, v polohe Barca-Baloty (Budinský-Krička 1968, 213-219; 1969, 231-235; Šiška 1971, 23-27; 1972a, 122-128).

\footnotetext{
5 Pôvodný názov lokality Prešov-Šarišské lúky (̌̌iška 1976, 83).

6 Dulová Ves, poloha Čergov II. Výskum spoločnosti Archeológia Zemplín, s. r. o., v rokoch 2012 a 2013 (nepublikované objekty 1, 1A a 2). Za informáciu d’akujeme Jurajovi Malecovi.
} 
Z vyššie uvedených informácií vyplýva, že za súčasného stavu výskumu sídlisk skupiny Lažňany na východnom Slovensku je možné komplex sídliskových jám z Ruskej porovnat' len s publikovanými objektmi z L’ubotíc, z miestnej časti Šarišské lúky. Z nich dva objekty (13 a 14) boli označené ako exploatačné jamy. Objekt 14, rozpoznaný v profile sondy $\mathrm{V}$, dosahoval dížku 4,5 m. Na jeho dne sa nachádzali viaceré preliačiny nepravidelných rozmerov s maximálnou híbkou do $0,70 \mathrm{~m}$. Objekt 15 bol vyhodnotený ako zásobná jama. Menej jednoznačná je interpretácia objektu 6, ktorý s prihliadnutím na tvar pôdorysu, schodovité výstupky a rovné dno S. Šiška $(1976,94)$ interpretoval ako pozostatok zemnice (Šiška 1976, 94). Paralelu k tomuto typu objektu uvádzal aj zo sídliska v Lúčkach, ktoré na základe odborného posúdenia nálezov datoval do prototiszapolgárskej fázy osídlenia (Šiška 1968, 131, 132, obr. 30).

Mimo územia Slovenska komplex eneolitických jám z Ruskej najviac pripomína nálezové situácie zaznamenané v areáli sídliska na lokalite Tiszalúc-Sarkad. Medzi zachovanými pôdorysmi prevažne dvojpriestorových kolových stavieb pochádzajúcich z osídlenia kultúry Hunyadihalom sa v tejto polohe na viacerých miestach zdokumentovali skupiny jám asymetrických tvarov. Takéto zoskupenia vznikali rozširovaním a spájaním viacerých jám híbených za účelom exploatácie hliny. Podla zachovaných pôdorysov nadzemných kolových stavieb vieme, že väčšie domy presahovali dížku $9 \mathrm{~m}$ a ich šírka závisela od celkovej dížky stien. Rozmernejšie stavby boli široké od 5,2 do 6,5 m, pričom najmenšia z nich šírkou nepresiahla 4,1 m. V spleti pôdorysov dvojpriestorových domov sa v Tiszalúcu podarilo rozpoznat aj jednu jednopriestorovú stavbu. Predpokladá sa, že na výmaz jedného obytného objektu bolo potrebné vytažit od 15 až do $25 \mathrm{~m}^{3}$ hliny. Odhadom sa teda dá pripustit, že hlina z jedného exploatačného komplexu mohla postačovat na výmaz stien jedného príbytku (Patay 2005, 50, 51, 56).

Ak zohl'adníme všetky poznatky ohladom stavebných zručností obyvatel'stva kultúry Hunyadihalom a skonfrontujeme ich s nálezovými situáciami opísanými z Ruskej, z časti zasahujúcej do areálu sídliska skupiny Lažňany, tak zásadnú zhodu medzi oboma sídliskami vidíme práve v spoločnom výskyte exploatačných jám vyhíbených v susedstve viac alebo menej zoskupených kolových jám. Nabáda nás to $\mathrm{k}$ úsudku, že aj v polohe Čierna zem mohli pôvodne stát nadzemné kolové stavby. Predpokladáme to aj s ohladom na stavebné praktiky obyvatel'stva s materiálnym prejavom tiszapolgárskej kultúry, z osídlenia ktorého sa v minulosti na Východoslovenskej nížine podarilo zdokumentovat minimálne devät pôdorysov nadzemných kolových konštrukcií, prípadne ich častí. Z výskumnej dokumentácie skúmanej plochy v Lúčkach je zrejmé, že tento typ príbytkov sa na sídlisku vyskytoval spolu s nadzemnými obydliami, ktoré mali dlážku viac alebo menej zapustenú pod vtedajšiu úroveň terénu (Šiška 1968, 130-138). Je teda vel'mi pravdepodobné, že zvyklost’ konštruovania oboch typov príbytkov mohla byt vlastná aj obyvatel'stvu materiálneho habitu skupiny Lažňany v období zavíšenia éry staršieho eneolitu. $\mathrm{V}$ nasledujúcej etape praveku, $\mathrm{v}$ čase sformovania sa skupín obyvatel'stva badenského kultúrneho komplexu, sa podoba sídlisk $\mathrm{v}$ regiónoch severne a severozápadne od Tisy výrazne zmenila. Z tohto osídlenia sa nám nezachovali takmer žiadne stopy po obydliach. Absentujú sídliskové objekty, ktoré by sme mohli jednoznačne interpretovat ako pozostatky nadzemných kolových chát. Objekty súvisiace $\mathrm{s}$ výstavbou domov zahíbených do zeme sú taktiež vel’mi zriedkavé. Doterajší výskum naznačil, že od uvedenej doby muselo praveké obyvatel'stvo, zrejme pod vplyvom viacerých závažných bližšie nešpecifikovaných zmien, zásadne zmenit sídliskovú stratégiu. Omnoho flexibilnejšie sa muselo prispôsobit novým prírodným a životným podmienkam, čo vyústilo k zásadnej zmene hospodárstva. Okrem už osídlených oblastí severného Potisia v krátkom časovom úseku osadenstvo preniklo aj do dovtedy málo alebo vôbec neosídlených regiónov, kde popri dostupných otvorených a ostrožných polohách vedome vyhl'adávalo aj t’ažšie prístupné a prirodzene chránené lokality. Novým a zásadne odlišným javom tohto obdobia bolo zakladanie ohradených, v niektorých prípadoch dokonca umelo opevnených ostrožných a výšinných sídlisk a nástup nového hospodársky efektívnejšieho fenoménu - pastierstva (Horváthová 2010, 28-30; 2015, 381-391; Horváthová/Nevizánsky 2017, 39-48).

\section{ANALÝZA KERAMICKÉHO MATERIÁLU}

Z vyššie uvedeného opisu archeologického materiálu vyplýva značná torzovitost keramických nálezov. Identifikované boli zlomky mís, hrncovitých nádob, amfor, štvorhranných kalichov, jednej pokrievky a zásobných nádob. $Z$ drobných predmetov vyrobených $\mathrm{z}$ hliny sa zachoval len fragment kolieska.

Dom 24 . 


\section{Misy}

Z preskúmaných sídliskových jám sa nám podarilo kresbovo zrekonštruovat dve misy pochádzajúce z výplne objektu 94 (tab. VII: 3, 4). Ak ich porovnáme s keramickými nálezmi z pohrebísk z Malých Zalužíc-Lažnian, Šebastoviec a Košíc (z Barce-Baloty), vidíme ich podobnost’ k miskám typu II, konkrétnejšie k ich variantu IIa (Šiška 1972a, tab. III: 3; VI: 7; VII: 2, 6; X: 2, 9, 12). Misy tohto typu sa objavili už v starších chronologických úsekoch polgárskeho kultúrneho komplexu, no zvýšenie ich produkcie je evidentné až od horizontu pohrebísk a sídlisk skupiny Lažňany. Misy typu II sa vyznačujú vel’mi zaobleným telom a výrazne odsadeným hrdlom cylindrického alebo viac-menej lievikovitého tvaru. V predchádzajúcich skupinách polgárskeho komplexu boli zriedkavé. Častejšie sa vyskytovali až v najmladších hroboch na pohrebisku v Tiszapolgári-Basatanyi (Bognár-Kutzián 1963, tab. CXIII: 13, 14). Na prvom fragmente misy sa zachovalo len jedno malé nezdobené ucho s horizontálnym otvorom (tab. VII: 3). Pôvodne bolo umiestnené na pleciach nádoby pod hrdlom. Druhý zlomok misy má na tom istom mieste prilepené ucho typu Scheibenhenkel vyznačujúce sa lalokovito formovaným výčnelkom (tab. VII: 4). Tvar nádoby a orientovanie ucha s vertikálnym otvorom, vrátane lalokovito formovaného výčnelku sa podobajú niektorým fragmentom nádob zo sídliska kultúry Hunyadihalom v Tiszalúcu (Patay 2005, tab. 17: 18; 47: 3, 4, 6). K dalším výzdobným prvkom aplikovaným na nádobách sledovanej východoslovenskej kultúrnej skupiny i kultúry Hunyadihalom patria z vnútra vytlačené vypukliny (Patay 2005, tab. 37). Na povrchu jednej takejto misy z nekropoly v Šebastovciach sa spolu s vypuklinami nachádzali aj dve malé uchá (Šiška 1972a, 130, obr. 29: 2; tab. IV: 8). Na telách d’alších mís je zvnútra vytlačených šest', ba dokonca až osem vypuklín (Košice, Barca-Svetlá IV - Šiška 1970, 29, obr. 1; Malé Zalužice-Lažňany - Budinský-Krička 1964, 88). Črep s podobnou výzdobou poznáme aj z Vel'kého Šariša (Budinský-Krička 1964, 100, obr. 11: 9). Z Ruskej tiež evidujeme dva keramické zlomky naznačujúce výzdobu tohto typu (tab. V: 4, 7). Viaceré zlomky sú tvarom podobné malým miskám. Na každom z nich sa zachovali miniatúrne perforované i neperforované výčnelky, pripomínajúce pseudouchá, resp. pseudovýčnelky. Umiestnené boli tesne pod okrajom nádobky (tab. V: 13), na vydutine jej tela (tab. II: 2), alebo na pleciach pod odsadeným hrdlom (tab. IV: 7, 12; VI: 5). V objekte 92 sa objavil aj zlomok z menšej nádobky hranatého tvaru, ktorá mala pri okraji minimálne jedno perforované pseudoucho (tab. IV: 3). Zachované fragmenty mís z polohy Čierna zem v porovnaní s misami z Tiszalúcu na prvý pohl’ad nie sú tak bohato zdobené. Zásadný rozdiel sledujeme v absencii rytých a žliabkovaných (kanelovaných) výzdobných vzorov.

\section{Hrnce}

Z objektu 90 pochádzajú zlomky hrnca so zvislým, vyšším a výrazne odsadeným hrdlom, na ktorom bolo nalepené minimálne jedno masívne ucho typu Scheibenhenkel, dozdobené okrem výčnelku lalokovitého tvaru aj pozdížnym plastickým rebrom (tab. I: 4). Fragmenty druhého hrnca, vyzdvihnuté z objektu 92, vykazujú známky nádoby s výraznejšie vyhnutým a odsadeným hrdlom, pod ktorým sa len v náznakoch zobrazuje tenká ryha. Na ňom sa pôvodne nachádzali dve uchá typu Scheibenhenkel prečnievajúce nad okraj nádoby (tab. III: 4). Opísané fragmenty možno stotožnit’ s dvojuchými hrncami typu I (variant Ia), ktoré sú v rámci horizontu pamiatok polgárskeho kultúrneho komplexu príznačné predovšetkým pre materiálnu kultúru skupiny Lažňany, no takmer v identickej podobe sa objavili aj na sídlisku kultúry Hunyadihalom v Tiszalúcu (Patay 2005, tab. 41: 1, 3, 5, 6; 42: 1, 5; Šiška 1971, 131). Uniformné podoby hrncov sa navzájom odlišujú len úpravou, umiestnením a formovaním tvarov úch. Na lokalitách z Košickej kotliny majú hrnce okraje často zdobené pretláčanými alebo presekávanými ryhami s výsledným efektom evokujúcim zvlnený tvar ústia (Budinský-Krička 1969, 232, 234, obr. 1: 5, 6, 9; Šiška 1972a, tab. IV: 1; V: 14, 16; VI: 3; VII: 1, 3, 7; IX: 3; X: 8, 11, 13; XI: 4, 7, 8, 10). Naopak, na lokalitách Východoslovenskej nížiny sa keramika s takouto výzdobou takmer neobjavuje. Potvrdzujú to aj nálezy z preskúmaných objektov z Ruskej, medzi ktorými sa podobne dekorované okraje vyskytli len sporadicky, no vzhladom na ich výraznú fragmentárnost̉ nedokážeme posúdit pôvodný typ nádoby, z ktorej pochádzajú (tab. IV: 6, 8, 9, 15; V: 8, 11, 12; VII: 2). Nevylučujeme teda, že niektoré z nich mohli patrit aj bezuchým hrncom typu II (pozri Šiška 1971, tab. VII: 8; VIII: 3; X: 1, 5). Z nádob menšieho objemu zaradených k typu I (variant Ia) pochádzajú tri vyobrazené črepy z objektov 90 a 92 (tab. I: 3; IV: 1, 2). Domnievame sa, že ich naznačené menšie tvary možno odvodit od hrnčekov s uškami na hrdle, ktoré na pohrebisku v Malých Zalužiciach-Lažňanoch patrili k druhému najčastejšiemu typu keramiky (Budinský-Krička 1964, 101, obr. 4: 7; 5: 4; 7: 2, 5, 5a; Šiška 1972a, 132, tab. III: 5). Zlomky identických nádob sú známe aj zo sídlisk vo Vel'kom Šariši (Budinský-Krička 1964, 100, obr. 11: 1) a Tiszalúcu (Patay 2005, tab. 48: 5). 


\section{Amfory}

Amfory sa vyznačujú užším cylindrickým alebo mierne kónickým hrdlom a širším baňatým telom. Ich základným znakom sú dve uchá situované na rozhraní hrdla a tela. Zlomky minimálne dvoch takýchto nádob boli identifikované vo výplni objektu 92. Na fragmente hornej časti menšej amfory sa zachovalo jedno z dvoch horizontálne perforovaných úch (tab. III: 2). Z druhej amfory pochádzajú tri črepy. Jej súčastou bolo ulomené ucho typu Scheibenhenkel a tri malé oválne výčnelky (tab. III: 3). Amforám mohli patrit aj d’alšie kresbovo zrekonštruované keramické zlomky. Jeden takýto fragment pochádza z objektu 92 (tab. 3: 1) a druhý sa vyskytol v objekte 94 (tab. VII: 1). Analyzovaný typ nádob sa na lokalitách skupiny Lažňany objavuje rovnako na sídliskách ako aj na pohrebiskách. Na žiarovom pohrebisku v Malých Zalužiciach-Lažňanoch amfory dokonca patrili k najčastejšie vyskytujúcim sa keramickým tvarom (Budinský-Krička 1964, 100). Stanislav Šiška medzi amforami východoslovenskej skupiny Lažňany rozlíšil dva varianty. K variantu Ia zaradil nádoby s vysokými nad okraj prečnievajúcimi pásikovými uchami (Šebastovce - Šiška 1972a, tab. IV: 6; V: 12; Košice-Barca - Šiška 1972a, tab. XII: 1). Obmeny podobných nádob nachádzame v bodrogkeresztúrskej kultúre, s ktorou sa spája výroba mliečnikov. Na lokalitách skupiny Lažňany sa s nimi stretávame vel’mi výnimočne. Vzdialenú analógiu $\mathrm{k}$ nim nachádzame len $\mathrm{v}$ nádobe z hrobu 8 zo Šebastoviec (Šiška 1972a, tab. V: 12). Početnejšie zastúpenie majú amfory variantu Ib, ktorých profilácia je podobná amforám variantu Ia. Odlišujú sa len umiestnením úch na rozhraní hrdla a tela a taktiež plastickou výzdobou tela v podobe zvnútra vytlačených plastických prvkov (Lažňany - Šiška 1972a, tab. III: 1, 10; Šebastovce - Šiška 1972a, obr. 29: 1, 6; 30: 2, 7; Košice-Barca, poloha Baloty - Šiška 1972a, tab. XI: 5, 11; XII: 3). Na amforách oboch variantov sa objavili stopy po čiernom smolnom nátere (Košice-Barca, poloha Baloty - Šiška 1972a, tab. XII: 1; Šebastovce - Šiška 1972a, tab. IV: 4; XII: 3). Nádoby podobné amforám variantu Ib môžeme rozpoznat aj v kultúre Hunyadihalom, avšak s tým rozdielom, že ich kónické hrdlá sú v porovnaní s amforami skupiny Lažňany užšie a vyššie (Patay 2005, tab. 6-8).

\section{Štvorhranné kalichy}

Súčastou sídliskovej keramiky z Ruskej boli minimálne dve nádoby štvorhranného tvaru, ktoré sa v podobe zlomkov šiestich črepov zachovali v dvoch objektoch (93 a 94). Prvému kalichu pripisujeme dva zlomky z objektu 93. Pochádzajú z dolnej časti nádoby, z rozhrania dna a šikmej steny (tab. V: 16). Druhému kalichu patrili tri keramické zlomky z objektu 94 - konkrétne úlomok z okraja ústia, steny a dna (tab. VI: 3, 4, 6). Fragmenty štvorhranných nádob z Ruskej sú zdobené vtlačenými jamkami umiestnenými na hranách zalomených stien. Takáto výzdoba sa na ostatných nepočetných kalichovitých nádobách skupiny Lažňany nevyskytuje. Naopak, často sa objavuje na keramike tohto typu nádob v kultúre Hunyadihalom, avšak s tým rozdielom, že je omnoho dekoratívnejšia (Patay 2005, tab. 19: 4, 7; 20: 4; 21: 9, 11, 13). Výzdobný detail na kalichu z objektu 94 tvoril jednoduchý lalokovitý výčnelok, ktorý pôvodne spolu s d’alšími lalokovitými výčnelkami presahoval nad ústie nádoby (tab. VI: 3). Z Košíc, z lokality Barca-Svetlá IV (z jamy 1a) pochádza kalich so štyrmi vysoko vytiahnutými lalokmi na rohoch. Jeho nezdobené steny sa kónicky zužujú smerom k obdížnikovitému dnu. Na užších stranách tela sa nachádzajú dve malé pásikové ušká (Bánesz 1970, 326, obr. 2: 2). Z tej istej lokality je známy aj fragment dna štvorhrannej nádoby, ktorý sa údajne vyskytoval $\mathrm{v}$ sprievode inokultúrnej keramiky bolerázskeho typu (Bánesz 1970, 326, obr. 1: 15). Ďalší zlomok evidujeme aj z pohrebiska v Šebastovciach, zo žiarového hrobu 34 (Šiška 1972a, tab. VIII: 9). ${ }^{8}$ V susednom kostrovom hrobe 33 sa v rámci hrobovej výbavy zachoval aj vysoký nezdobený kalich s ústím modelovaným do štyroch lalokov, ktorého súčastou sú dve nezdobené uchá (Šiška 1972a, 136, tab. VIII: 4, 9). ${ }^{9}$ Z východného Slovenska, teda vrátane nepublikovaného nálezu štvorhranného kalicha z Bidoviec (Hreha 2016, 100) ${ }_{1}^{10}$ môžeme v zlomkoch alebo po čiastočnej rekonštrukcii doložit sedem exemplárov nádob tohto typu. Najstaršie im podobné predlohy sa na území Karpatskej kotliny znova spájajú s osídlením bodrogkeresztúrskej kultúry (Patay 1975, tab. 15: 5; 1976, 181, tab. IV: 2). Z nasledujúceho osídlenia kultúry Hunyadihalom ich už poznáme takmer zo všetkých známych sídlisk (pozri Patay 2005, 84, tam dalšia citovaná literatúra). Len z lokality Tiszalúc pochádza 714 keramických zlomkov, z ktorých sa podarilo zrekonštruovat devät štvorhranných kalichov (Patay 2005, 82). Spravidla

\footnotetext{
8 Nálezy z hrobu 34 - malá baňatá nádoba s cylindrickým hrdlom s dvomi uškami; pôvodne dvojuchá amfora, fragment dna štvorhrannej nádoby, retušovaný predmet z rádiolaritu (Šiška 1972a, 119, obr. 17: 34; tab. VIII: 2, 9, 10).

9 Nálezy z hrobu 33 - baňatá nádoba s kónickým hrdlom a dvomi uškami, štvorhranný kalich vysoký 11,2cm; zlomky keramiky z d’alších nádob, kamenná industria - 3 ks (Šiška 1972a, 118, 119, obr. 30: 7; 38: 4, 5, 16; tab. VIII: 4, 6).

10 Rastislavovi Hrehovi d’akujeme za sprístupnenie nálezu.
} 
majú vyhladený povrch a reprezentujú typ jemnej keramiky. Súčastou niektorých z nich je vnútorná priečka, ktorá im dáva podobu dvojdielnych nádob (Kalicz 1980, 45, obr. 2: 10; Patay 2005, tab. 22: 1, 3). Viaceré kalichy kultúry Hunyadihalom sa od kalichov skupiny Lažňany odlišujú tvarom a výzdobou bázy, ${ }_{1}^{11}$ výraznejšou plastickou výzdobou ${ }^{12}$ a objavením sa rytého ornamentu. ${ }^{13}$ Za spoločný znak nádob tohto typu považujeme uniformný tvar ústia, ktoré je takmer vždy formované do podoby štyroch prečnievajúcich zaoblených rohov. ${ }^{14}$

\section{Pokrievky}

Fragment pokrievky diskovitého tvaru s jedným zachovaným uškom na hrane plochého okraja vyzdvihnutý z objektu 90 v Ruskej patrí v keramickom inventári skupiny Lažňany nateraz k ojedinelým nálezom (tab. I: 1). V príbuznom kultúrnom prostredí v Mad’arsku sa pokrievky tohto typu objavujú častejšie (pozri Tiszalúc - Patay 2005, 88, tab. 26: 1, 2, 5, 6; Hódmezővásárhely - Bognár-Kutzián 1969, obr. 1: $5 \mathrm{a}, 5 \mathrm{~b})$. Ich súčastou je nápadná dekoratívna výzdoba. Za jej jednoduchší variant možno považovat’ štyri malé pseudoušká (resp. výčnelky) umiestnené oproti sebe na obvode horného plochého okraja (pozri Patay 2005, tab. 26: 1). Práve s takýmto typom kuchynského náčinia možno stotožnit aj nájdený fragment z polohy Čierna zem. V preskúmaných objektoch zo sídliska chýbajú pokrievky kónického tvaru s držadlom, ktoré vo viacerých exemplároch poznáme z lokality Tiszalúc (Patay 2005, tab. 26: 10-15). Z pohrebísk a sídlisk skupiny Lažňany, s výnimkou jedného exemplára zo Šebastoviec (z hrobu 20), sú pokrievky kónického tvaru s držadlom taktiež neznáme (Šiška 1972a, 137, tab. VI: 9; 1972b, 6, tab. I: 5). Doterajšie nálezové okolnosti teda môžu poukazovat na skutočnost', že tento typ doplnkového kuchynského riadu bol v skupine Lažňany na území severne od Tisy v tom čase už na ústupe (Šiška 1972a, 137). Tradíciu výroby pokrievok na východnom Slovensku totižto sledujeme už od mladšej etapy neolitu v potiskej kultúre (Čičarovce, objekt A/76 - Vizdal, J. 1980), v skupine Tiszapolgár-Csőszhalom-Oborín (Hrčel, Oborín - Kaminská 1987, obr. 6: 5; Vizdal, J. 1961, obr. 10: 2; 11: 7, 8; 14: 1, tab. IV), no najmä v mladšom období v tiszapolgárskej kultúre, kde bol hojný výskyt pokrievok i pestroste ich držadiel, a to už od jej najrannejšej fázy (Vel'ké Raškovce, Lúčky, Šiška 1968, obr. 7: 3; 9: 19; 10: 2). Tento stav je opät príznačný len pre materiálnu výbavu východoslovenskej zložky osadenstva tiszapolgárskej kultúry. V ostatných jej enklávach mimo východného Slovenska sa kónické pokrievky vyskytujú len vel’mi zriedkavo (Šiška 1972a, 103, tu d’alšia citovaná literatúra). Toto tvrdenie sa však nevztahuje na nálezy bodrogkeresztúrskej kultúry, odkial' pokrievky takisto evidujeme (Bognár-Kutzián 1963, tab. CXXXII: B 2a, 2b; Patay 1961, tab. XVII: 2).

\section{Zásobnicové nádoby}

Na výskyt tohto typu keramiky by mohol poukazovat zlomok člnkovitého ucha so zvislým otvorom objavený v objekte 94 (tab. VI: 7). Jemu podobné ucho pochádza aj z objektu 92 (tab. V: 3). Masívne uchá člnkovitého, ale aj pásikového tvaru boli spravidla situované na maximálnej vydutine alebo pod vydutinou väšších nádob (Malé Zalužice-Lažňany - Šiška 1972a, 135, tab. III: 9, 11, 14; Šebastovce - Siška 1972a, tab. VI: 10; Košice, poloha Barca-Baloty - Šiška 1972a, tab. X: 7). V geografickom priestore severného Potisia nachádzame k člnkovito tvarovaným uchám početné analógie na keramike z neskorého neolitu, v tiszapolgárskej kultúre s ich prevahou vo východiskovej prototiszapolgárskej fáze (Šiška 1964, 197, obr. 12: 27; 25: 24; 1968, 78, 104, 111, obr. 5: 9, 12, 14; 6: 10; 9: 13, 14; 19: 4) a ako výzdobný element sa vyskytli aj na nádobách kultúry Hunyadihalom (Patay 2005, 104; tab. 46: 6, 8).

\section{Hlinené predmety}

Z drobných nálezov vyrobených z hliny sa v objekte 92 zachoval zlomok plochého predmetu kruhového tvaru. $V$ strede má naznačený otvor, pri ktorom sa jedna z jeho stien mierne rozširuje (tab. IV:

\footnotetext{
11 Spodná čast’ kalichov nemá hranatý, ale oválny tvar (Patay 2005, tab. 20: 2, 10). Báza je rozdelená do kríža na štyri rovnaké časti alebo je hladká a nachádzajú sa na nej malé bradavkovité nôžky (Patay 2005, tab. 20: 1-3; 20: 7).

12 Odtlačky prstov, nechtov, vrypy, zdvojené plastické výbežky, plastická výzdoba v podobe lalokovito formovaných výčnelkov typu Scheibenhenkel (Patay 2005, tab. 19: 5, 4, 7; 20: 4a, 14-18; 21: 1-4, 6-11).

13 Rytá výzdoba typu cik-cak (Patay 2005, tab. 21: 16).

14 (Patay 2005, tab. 20: 2, 10).
} 
14). Z lokalít skupiny Lažňany je to nateraz jediný nález hlineného drobného predmetu, ktorý poznáme. Interpretujeme ho ako zlomok vel'mi plochého praslena alebo kolieska (tab. IV: 14). Z kultúry Hunyadihalom poznáme minimálne štyri základné tvary praslenov (Patay 2005, tab. 53: 1-4). Nášmu nálezu je typovo najbližší plochý nezdobený praslen $\mathrm{v}$ tvare mlynského kameňa, ktorého priemer dosahuje $6 \mathrm{~cm}$ (Patay 2005, tab. 53: 4).

\section{Nálezy z kameňa}

V objekte 91 sa vyskytol pieskovcový kameň pozdĺžneho tvaru, na ktorom makroskopicky nepozorujeme stopy po opracovaní alebo používaní (tab. III: 3). Z objektu 93 pochádza otíkač a v objekte 94 sa našiel fragment zrnotierky. Nálezov zhotovených z dobre štiepatelných kamenných surovín sa v objektoch 90 až 94 zistilo viac ako 14 kusov. ${ }^{15}$ Z informácií, ktoré sú uvedené v prírastkovom katalógu z výskumu však nedokážeme precizovat celkový počet predmetov a ani typy surovín, z ktorých boli vyrobené. Pri niektorých záznamoch sa ale ako kamenná surovina uvádza obsidián, v jednom prípade aj rohovec. $Z$ typov nástrojov by podla prvotných záznamov mohli byt zastúpené zlomky čepelí a jedno škrabadlo. $Z$ d’alších predmetov súvisiacich s produkciou štiepanej industrie sa spomínajú aj úštepy.

\section{VYHODNOTENIE NÁLEZOV}

Zlomky keramiky skupiny Lažňany vyzdvihnuté zo sídliskových objektov z Ruskej (z polohy Čierna zem) svojimi tvarmi vrátane výzdoby pripomínajú typologickú škálu keramických milodarov objavených v žiarových hroboch v Malých Zalužiciach-Lažňanoch (v okr. Michalovce) a Velykich Lazoch (Zakarpatská Ukrajina). Pri ich konfrontovaní s hrnčiarskou produkciou kultúrne totožnej skupiny obyvatel'stva sídliaceho v Košickej kotline a v Šarišskom podolí, nálezy z lokalít Východoslovenskej nížiny vykazujú niektoré zhody i rozdiely. Tie sú pri porovnaní so súdobou keramikou kultúry Hunyadihalom v niektorých detailoch ešte výraznejšie.

Z vyššie uvedených analýz vyplývajú nasledovné zistenia:

- Sídlisková keramika z Ruskej je vel’mi jednoduchá na tvary a výzdobu.

- Na východoslovenských lokalitách skupiny Lažňany si tvary nami prezentovaných mís zachovali jednu z foriem známu už z najstaršieho chronologického úseku polgárskeho kultúrneho komplexu, ktorá bola v náplni tiszapolgárskej kultúry ${ }^{16}$ označená ako variant misy IIb (Šiška 1968, 105, obr. 11: 12; 12: 12; 35: 7). Mladšie tvary mís z obdobia stredného eneolitu mali v porovnaní s nimi zretelnejšie zaoblené telo a výraznejšie odsadené hrdlo cylindrického alebo viac-menej lievikovitého tvaru (Horváthová 2010, 53, obr. 16, 17, 18).

- V analyzovanom súbore chýbajú zlomky keramiky, ktoré by sme mohli typologicky zaradit k misám na dutej nôžke alebo k misám na štyroch nôžkach (pozri Šebastovce - Šiška 1972a, obr. 30: 1; 31: 3). Absentujú aj dalšie tvary nádob, ako napríklad hrnčeky s uškom presahujúcim cez okraj (Šebastovce - Šiška 1972a, obr. 30: 2). Spomenuté tvary nádob sú zastúpené len v západnej enkláve skupiny Lažňany vrátane kultúry Hunyadihalom.

- Pokrievky diskovitého a kónického tvaru patria v skupine Lažňany k ojedinelým nálezom (Ruská a Šebastovce). Naopak, v kultúre Hunyadihalom sa vyskytujú omnoho častejšie a sú v porovnaní so skupinou Lažňany výraznejšie zdobené.

- Funkčné a výzdobné plastické prvky sú na keramike z Ruskej nevýrazné. Niektoré z nich pripomínajú pseudouchá, resp. pseudovýčnelky. Evidované sú aj výčnelky oválneho tvaru, zvnútra vytlačené vypukliny a zvislé plastické rebro.

- Súčastou nádob boli aj uchá typu Scheibenhenkel. Tento charakteristický dekór ${ }^{17}$ sa všeobecne vyskytoval na keramike viacerých eneolitických kultúr a kultúrnych skupín Bodrogkeresztúr B/Vajska/ Lažňany/Hunyadihalom, taktiež v protobolerázskom stupni bolerázskej skupiny, dokonca i v kontex-

\footnotetext{
15 Predpokladáme, že kamenná industria je uložená v depozitári spoločnosti Archeológia Zemplín, s. r. o., prípadne v depozitári Zemplínskeho múzea v Michalovciach. Personálna reorganizácia spoločnosti Archeológia Zemplín, s. r. o., a časovo náročné rozsiahle rekonštrukčné práce v Zemplínskom múzeu v Michalovciach nám už dlhšiu dobu neumožňujú nálezy kamennej industrie z eneolitu dohladat', skompletizovat' a vyhodnotit.

16 Vrátane jej prototiszapolgárskej fázy.

17 Aplikovaný pod uchami, ale aj samostatne na telách nádob.
} 
toch Galatin a Sălcuţa IV, čo možno chápał ako jeden z fenoménov vtedajšej doby dokazujúci nadregionálne vztahy spoločenstiev Karpatskej kotliny a Balkánu (Kalicz/Horváth 2010, 424, 425; Zalai-Gaál 2016, 12).

- Z výzdobných prvkov a techník sa na keramike z Ruskej neobjavujú: ryhy (typické pre bodrogkeresztúrsku kultúru), kanelúry, vrypy, barbotino, aplikovaná zoomorfná plastika, oválne alebo tupé gombíkovité výčnelky nad uchami a brázdený vpich. Nezaznamenali sa ani stopy po čiernom smolnom nátere. Presekávané a pretláčané okraje sú na nádobách z Východoslovenskej nížiny, v porovnaní s keramikou západnej enklávy skupiny Lažňany taktiež zastúpené len v minimálnej miere.

- Vo všetkých regiónoch rozšírenia skupiny Lažňany dokážeme na príklade niektorých typov nádob a ich výzdoby sledovat plynulý vývoj od mladého, resp. neskorého neolitu až po záver staršieho eneolitu (pozri niektoré tvary mís, pokrievky, člnkovité uchá). Táto kontinuita je na východnom Slovensku prerušená nástupom badenskej kultúry, $v$ hrnčiarstve ktorej nachádzame len minimálnu spojitost̉ s predchádzajúcou keramickou produkciou. V nasledujúcom vývoji severného Potisia sa medzi „doživajúcou“ staroeneolitickou a "nastupujúcou“ stredoeneolitickou civilizáciou ako klúčové územie javí región rozšírenia kultúry Hunyadihalom. Práve na keramike tejto kultúry výraznejšie rozpoznávame inovatívne prvky ex post vlastné hrnčiarstvu bolerázskej skupiny a badenskej kultúry (šálky s uchom prečnievajúcim nad okraj, tvary amfor, misy na štyroch nôžkach, široké kanelúry na telách výrazne profilovaných mís, pretláčané okraje nádob, ploché gombíkovité výčnelky nad uchami, štylizovaná zoomorfná plastika aplikovaná na telách nádob).

- Drobné predmety vyrobené zo zvieracích kostí, parohoviny, schránok mäkkýšov, jantáru a farebných kovov sa v analyzovaných eneolitických objektoch z Ruskej nezistili. Chýbajú aj nálezy odlievacích téglikov.

\section{ZÁVER}

V procese vyhodnocovania starších i novších výskumov realizovaných na lokalitách východného Slovenska sa v dôsledku dostupnosti moderných metód datovania začali postupne zverejňovat prvé rádiouhlíkové dáta, ${ }_{18}^{18}$ ktoré precizujú časové rámce existencie a prelínania pravekých kultúr na území centrálnej Európy zasahujúcich aj do periférnych regiónov severne od Tisy.

Zo záujmového obdobia staršieho eneolitu máme z juhovýchodného Slovenska k dispozícii devät rádiouhlíkových dát (z nich osem AMS dát). Najstarší časový údaj sa vztahuje k osídleniu prototiszapolgárskej fázy tiszapolgárskej kultúry z Čičaroviec, ktoré bolo na základe vzorky zo sídliskového objektu

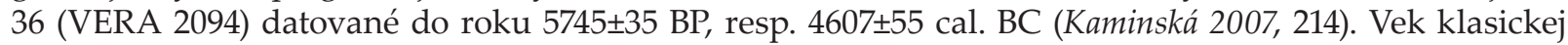
fázy tiszapolgárskej kultúry (Polgár III) určuje d’alšia vzorka z hrobu 1 z Malých Raškoviec zodpovedajúca veku 5427士29 BP (Brummack 2015, 259), čo sa podla výsledných hodnôt online programu calPal približuje veku $4298 \pm 30$ cal. BC. Tento časový údaj je porovnatelný s hodnotami datovania pohrebísk tiszapolgárskej kultúry z územia Madarska a Rumunska (Tiszapolgár-Basatanya, hrob 56 - Poz-36367, 5480 40 BP, hrob 36 - Poz-36364, 5470 40 BP; Raczky/Siklósi 2013, 558; Uivar, hrob 2 (F3476) - Poz-18973, 5470 40 BP, hrob 1 (F3443) - Poz-18972, 5440 \pm 40 BP, hrob 3 (F4174) - Poz-19390, 5410 \pm 40 BP; Brummack/Diaconescu 2014, 259; Schier 2013, 574; Hajdúböszörmény, hrob 71/75 - VERA-3786, 5445ะ35 BP, hrob 57/61 - VERA 3789, 5360 35 BP; Kovács/Váczi 2008, 408). Vysokú pravdepodobnost’ vykazujú aj rádiouhlíkové dáta zo sídlisk tiszapolgárskej kultúry z Békešskej župy v okrese Szeghalom, konkrétne z Körösladány-Bikeri

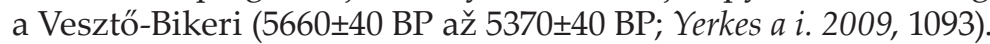

Z bodrogkeresztúrskej kultúry (Polgár IV) máme k dispozícii len dáta z mad’arských lokalít náležiacich do kultúrneho kontextu nálezísk Bodrogkeresztúr A až Bodrogkeresztúr B. Na tomto mieste uvádzame len rozpätie týchto dát od najstaršej po najmladšiu datovanú vzorku (Pusztataskony-Ledence

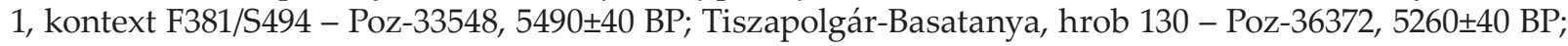
Raczky/Siklósi 2013, 559, 560). Len prednedávnom bolo z pohrebiska skupiny Lažňany z Košíc (z lokality Barca-Baloty) zverejnených osem AMS dát, z ktorých pre potreby d’alšieho výskumu možno akceptovat sedem dát (hrob 18 - MAMS-14243, 5208 \pm 27 BP, hrob 18 - MAMS-14244, 5102 \pm 24 BP, hrob 21 - MAMS14253, 5102 \pm 26 BP, hrob 17 - MAMS-14252, 5096 \pm 27 BP, hrob 22 - MAMS-14245, 5088 \pm 27 BP, hrob 21 - MAMS-14250, 5074 27 BP, hrob 18 - MAMS-14242, 5002 29 BP; Brummack 2015, tabela 2-5). Ich výsledné hodnoty naznačujú, že pochovávanie na pohrebisku pri Košiciach mohlo byt’ aktuálne medzi rokmi

\footnotetext{
18 Vrátane AMS dát s vysokou technickou presnostou a s dôsledným štatistickým prístupom.
} 


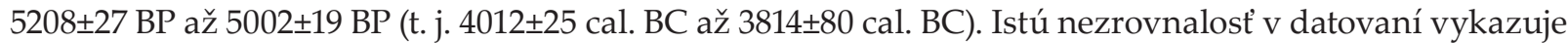
hrob 18, v rámci ktorého vzorky ludských kostí sú o 100 až 200 rokov staršie ako datovaná zoologická vzorka (Brummack 2015, 9). Zaujímavé je, že podobné chronologické odchýlky v datovaní ludských a zvieracích kostí evidujeme aj z Varny I (Higham a i. 2007, 646). ${ }^{19} \mathrm{Z}$ osídlenia kultúry Hunyadihalom máme k dispozícii tri AMS dáta z lokality Tiszalúc-Sarkad (hrob 2 - Poz-36361, 5070 40 BP, hrob 8 - Poz-

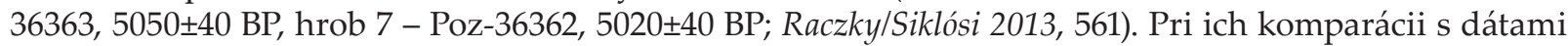
z Barce-Baloty sa pre kultúrny komplex Hunyadihalom-Lažňany zdá byt๋ akceptovatelný časový rozsah medzi rokmi 4000/3950 cal. BC až 3800/3750 cal. BC (Brummack 2015, 13). Ak tieto údaje skonfrontujeme s d’alšími AMS dátami zodpovedajúcimi najstaršiemu osídleniu badenskej kultúry na juhu východného Slovenska (Kašov, objekt 1/2011, 4575 BP-4480 BP, resp. 3498 cal. BC-3029 cal. BC; Baden I/II; Horváthová/Zastawny 2016, 964), tak medzi zánikom predošlého a objavením sa nového osídlenia v prechodnom bolerázsko-včasnoklasickom horizonte badenskej kultúry zistujeme neprimerane dlhý, takmer 300 ročný časový hiát. Naopak, najstaršie rádiouhlíkové dáta z lokalít západného Slovenska možno zaradit

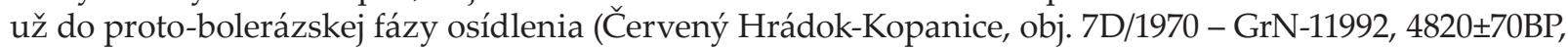

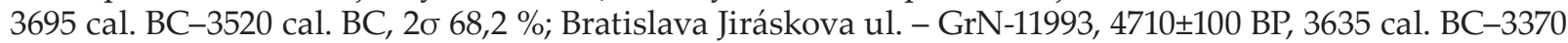
cal. BC, 20 68,2 \%; Horváth/Svingor 2015, 50; Němejcová-Pavúková 1985, 25; Wild a i. 2001, 1061). Záverom treba upozornit’ aj na skutočnost', že lokality s keramikou bolerázoidného typu, na ktoré $\mathrm{v}$ minulosti upozornil S. Šiška $(1972 b, 8 ; 1973,461,462 ; 1998,129)$ v súčasnosti evidujeme aj mimo centrálnej oblasti Košickej kotliny. V posledných rokoch k nim pribudli spolahlivo identifikované náleziská zo severnej periférie Košickej kotliny (Prešov, poloha Mestský cintorín, nepublikované) ${ }^{20}$ ale aj z Východoslovenskej nížiny (Kašov-Šarkan, Trebišov-Koval'ka; nepublikované). ${ }^{21} \mathrm{~S}$ výnimkou AMS dát z Kašova sa však na spomínaných lokalitách z bolerázsko-včasnoklasického horizontu Baden I/II, vrátane sídlisk skupiny Lažňany, neobjavili organické vzorky vhodné na rádiouhlíkové AMS analýzy. Historicko-archeologický vývoj juhu východného Slovenska v medziobdobí rokov 3800 až 3500 BC nám teda aj za súčasného stavu výskumu ostáva aj nadalej neobjasnený.

\footnotetext{
19 Príčiny odlišných datovaní ludských a zvieracích kostí pochádzajúcich z tých istých kontextov sú v štádiu výskumu.

20 Výskum Archeologickej agentúry, s. r. o.

21 Výskumy Archeológie Zemplín, s. r. o.
} 


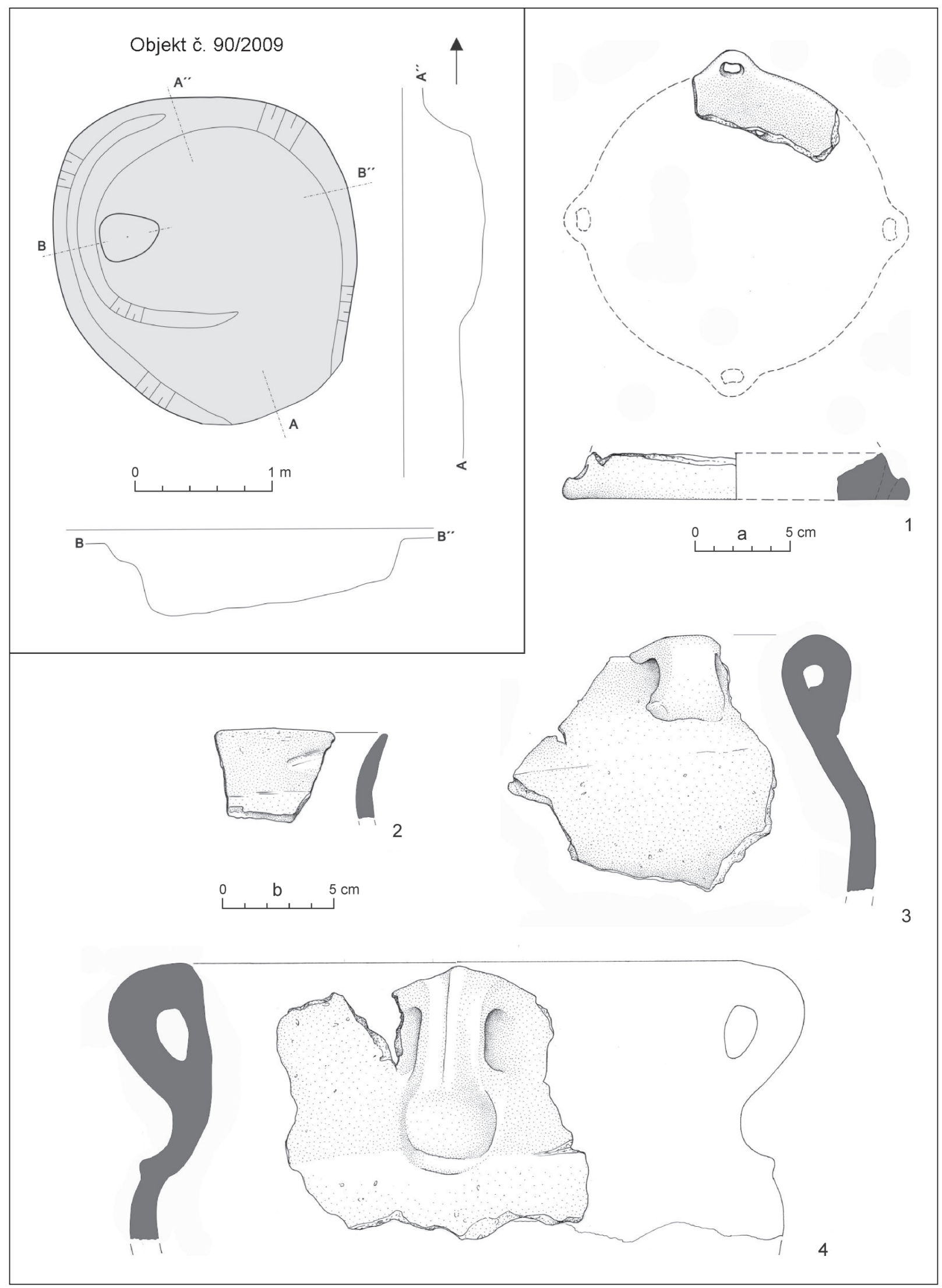

Tab. I. Ruská, poloha Čierna zem. Kresbová dokumentácia objektu 90. 1-4 - výber nálezov z objektu 90. Mierka: a - 1; b-2-4 (kresby keramiky a grafická úprava P. Šimčík). 


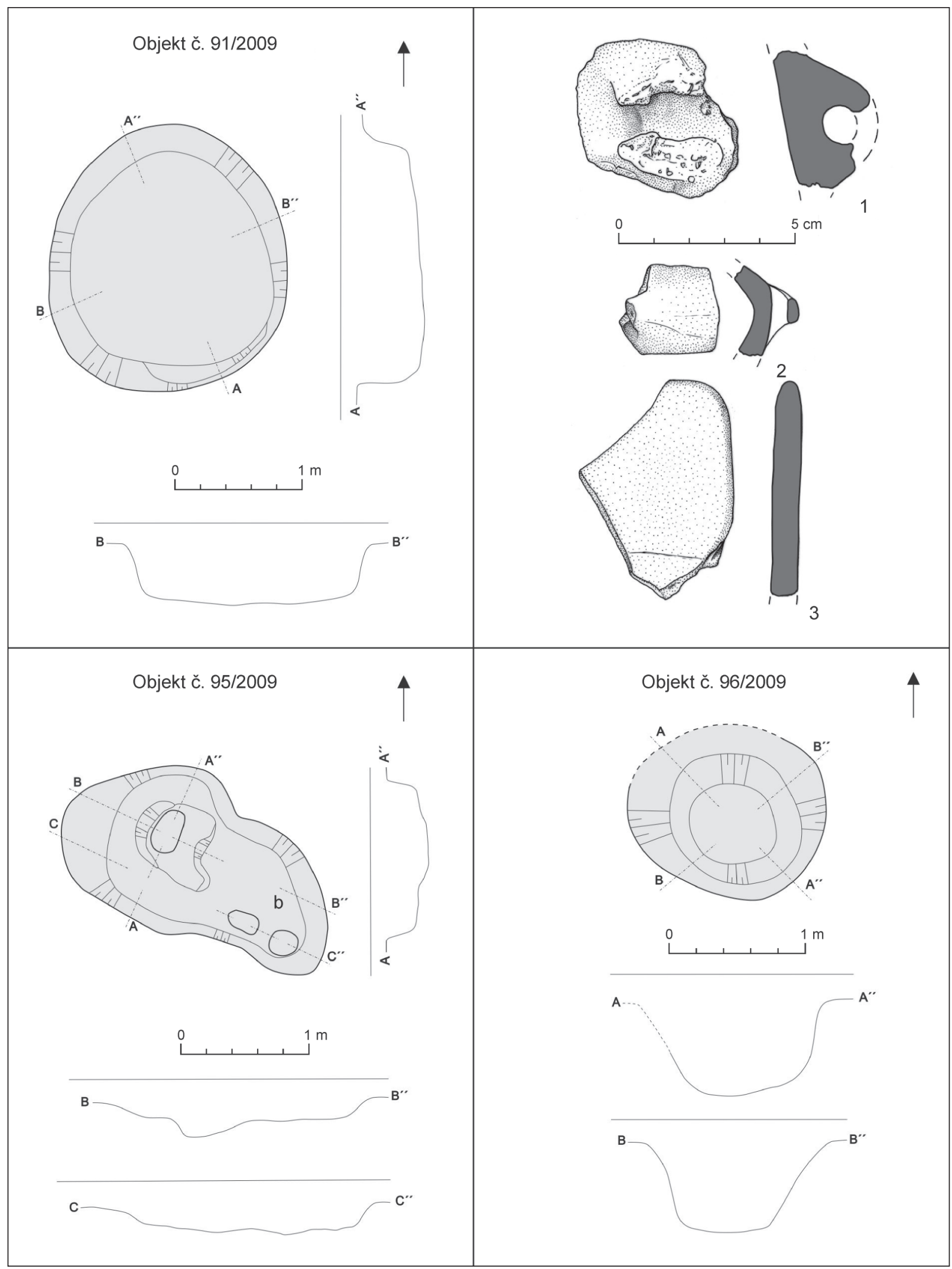

Tab. II. Ruská, poloha Čierna zem. Kresbová dokumentácia objektov 91, 95, 96. 1-3- výber nálezov z objektu 91 (kresby keramiky a grafická úprava P. Šimčík). 


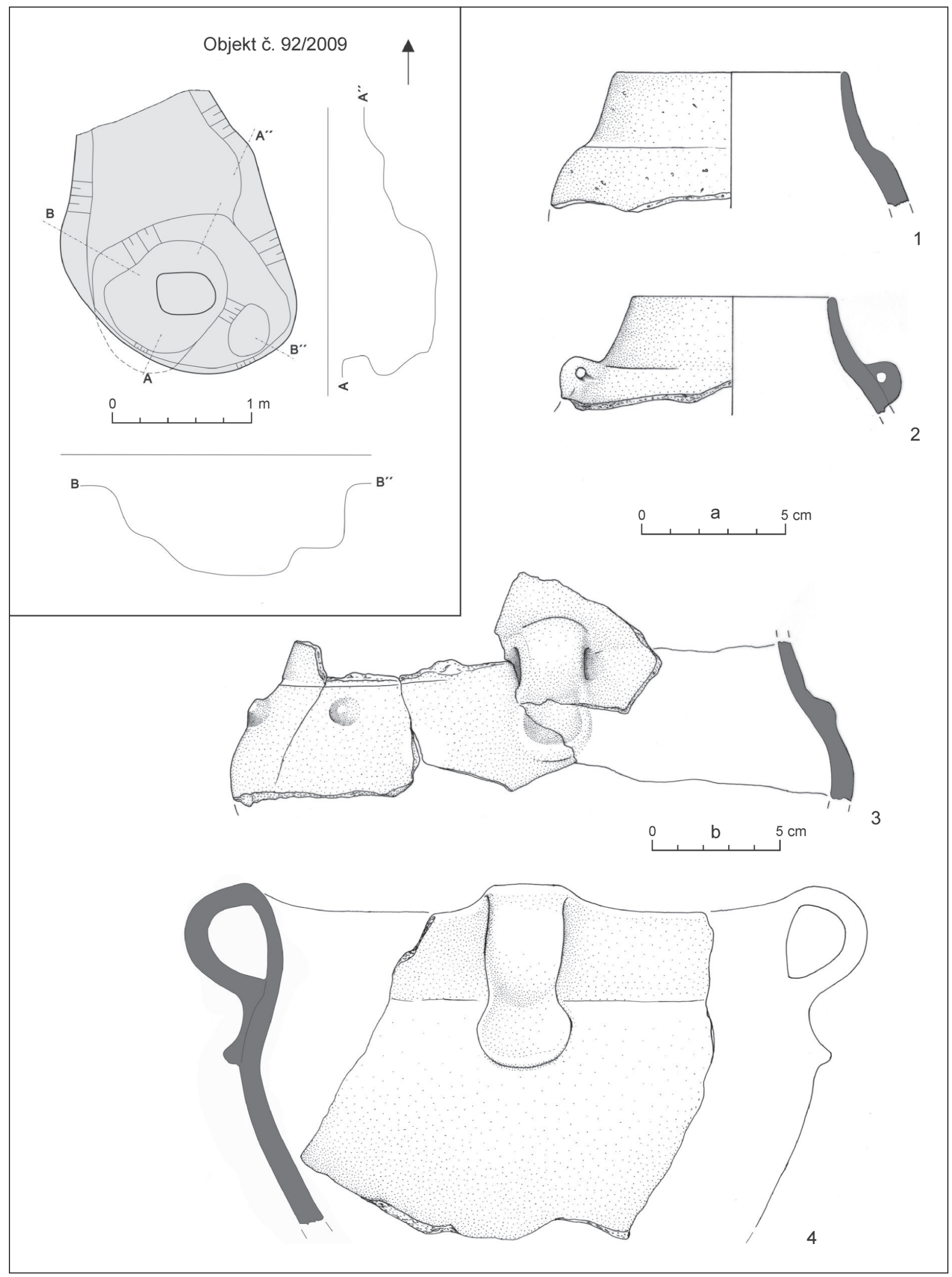

Tab. III. Ruská, poloha Čierna zem. Kresbová dokumentácia objektu 92. 1-4 - výber nálezov z objektu 92. Mierka: a - 1, 2; b-3, 4 (kresby keramiky a grafická úprava P. Šimčík). 


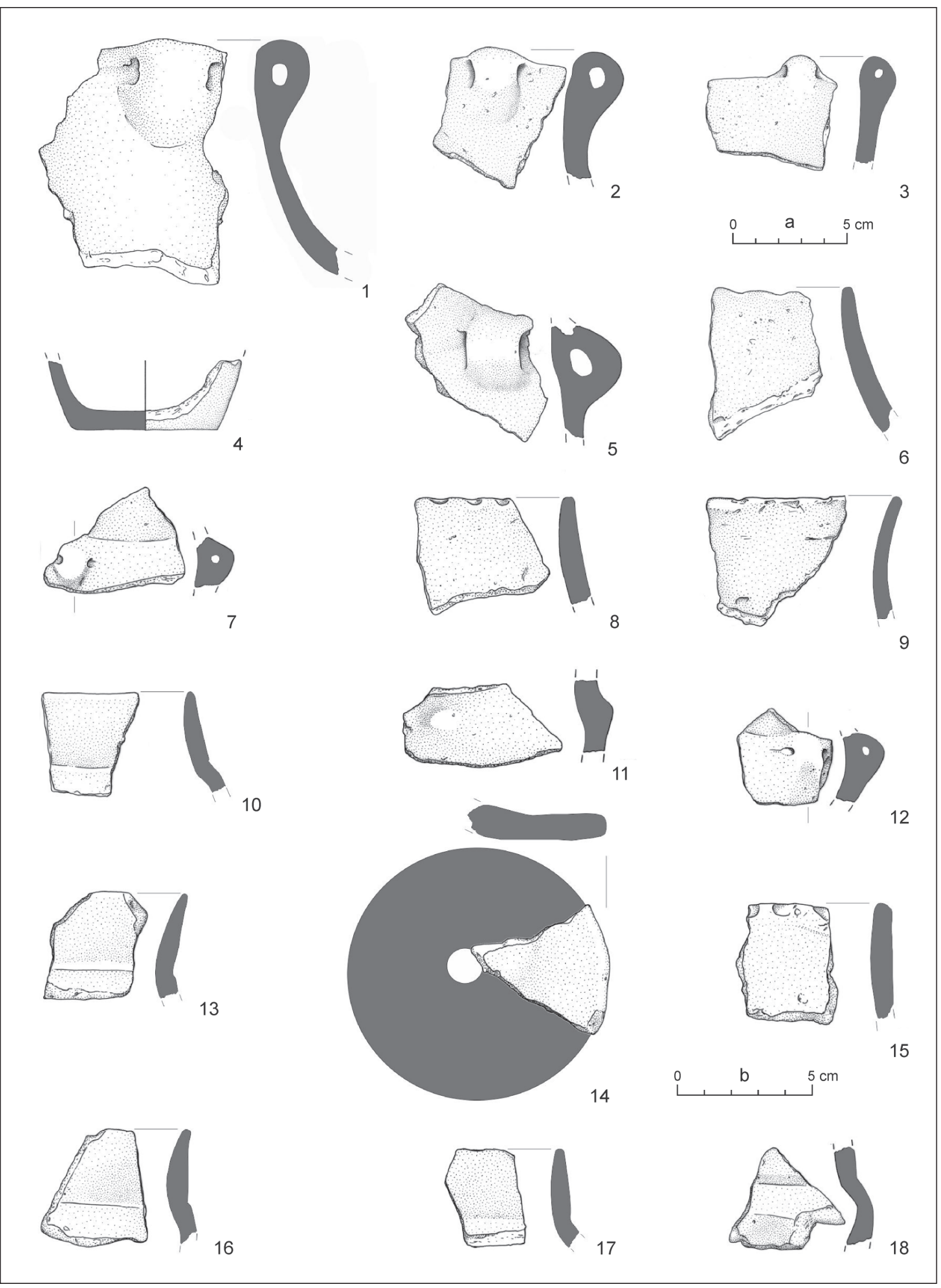

Tab. IV. Ruská, poloha Čierna zem. Výber nálezov z objektu 92. Mierka: a - 1-6; b-7-18 (kresby keramiky a grafická úprava P. Šimčík). 


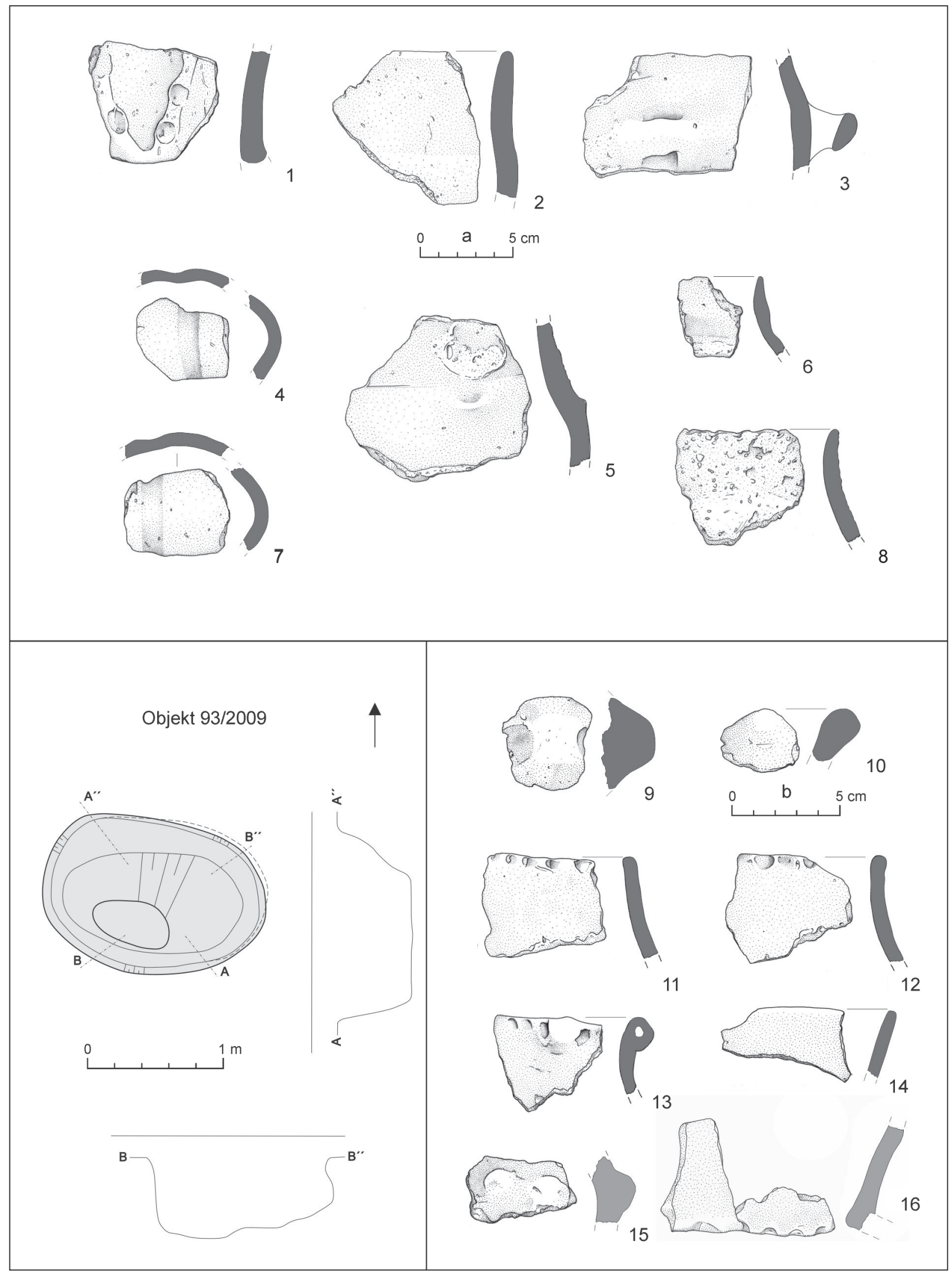

Tab. V. Ruská, poloha Čierna zem. Kresbová dokumentácia objektu 93. 1-8 - výber nálezov z objektu 92; 9-16 - výber nálezov z objektu 93. Mierka: a -1-8; b-9-16 (kresby keramiky a grafická úprava P. Šimčík). 
NOVOOBJAVENÉ SÍDLISKOVÉ NÁLEZY SKUPINY LAŽŇANY Z RUSKEJ, OKRES MICHALOVCE

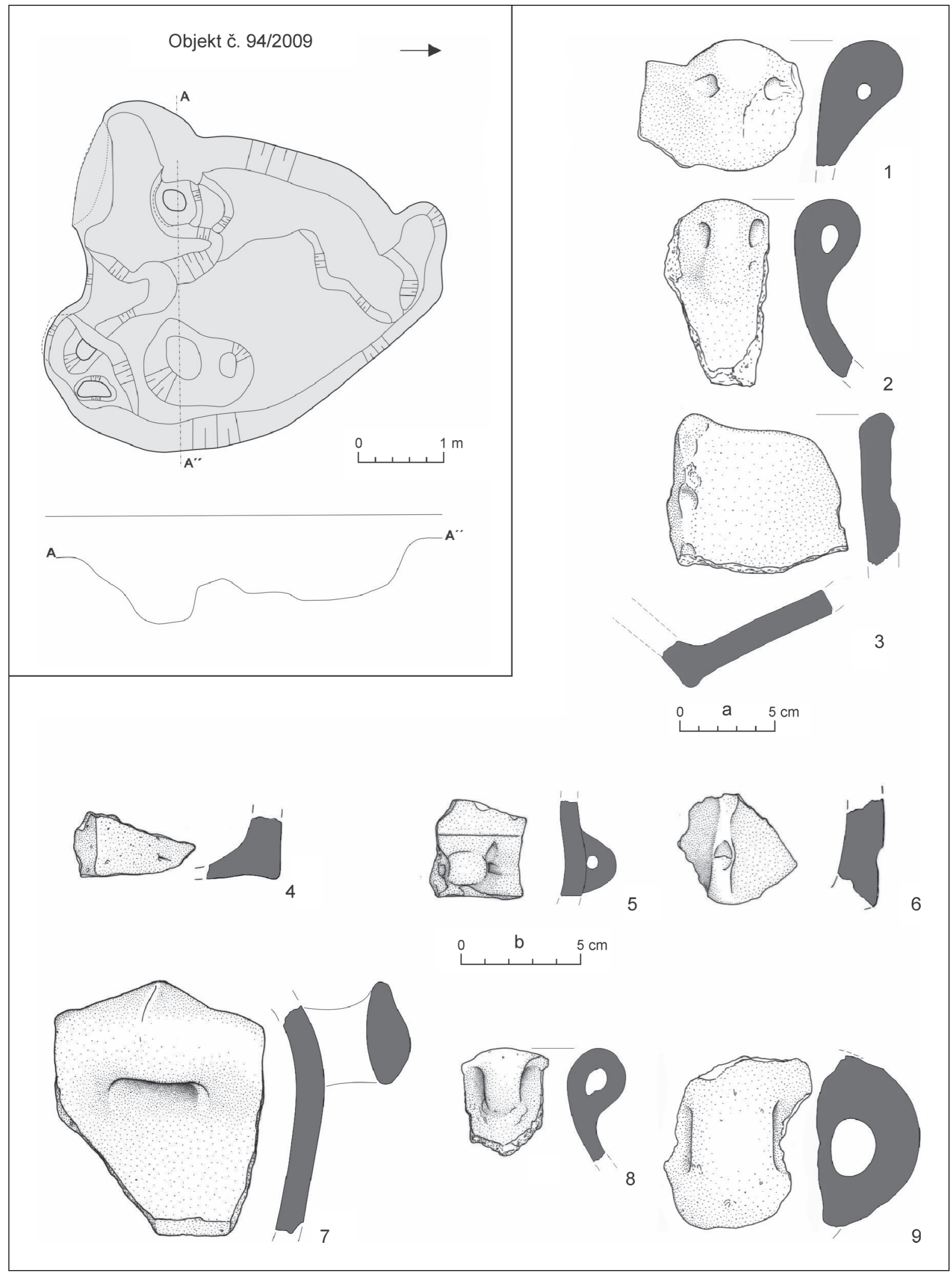

Tab. VI. Ruská, poloha Čierna zem. 1-4 - výber nálezov z objektu 93 (kresby keramiky a grafická úprava P. Šimčík). 


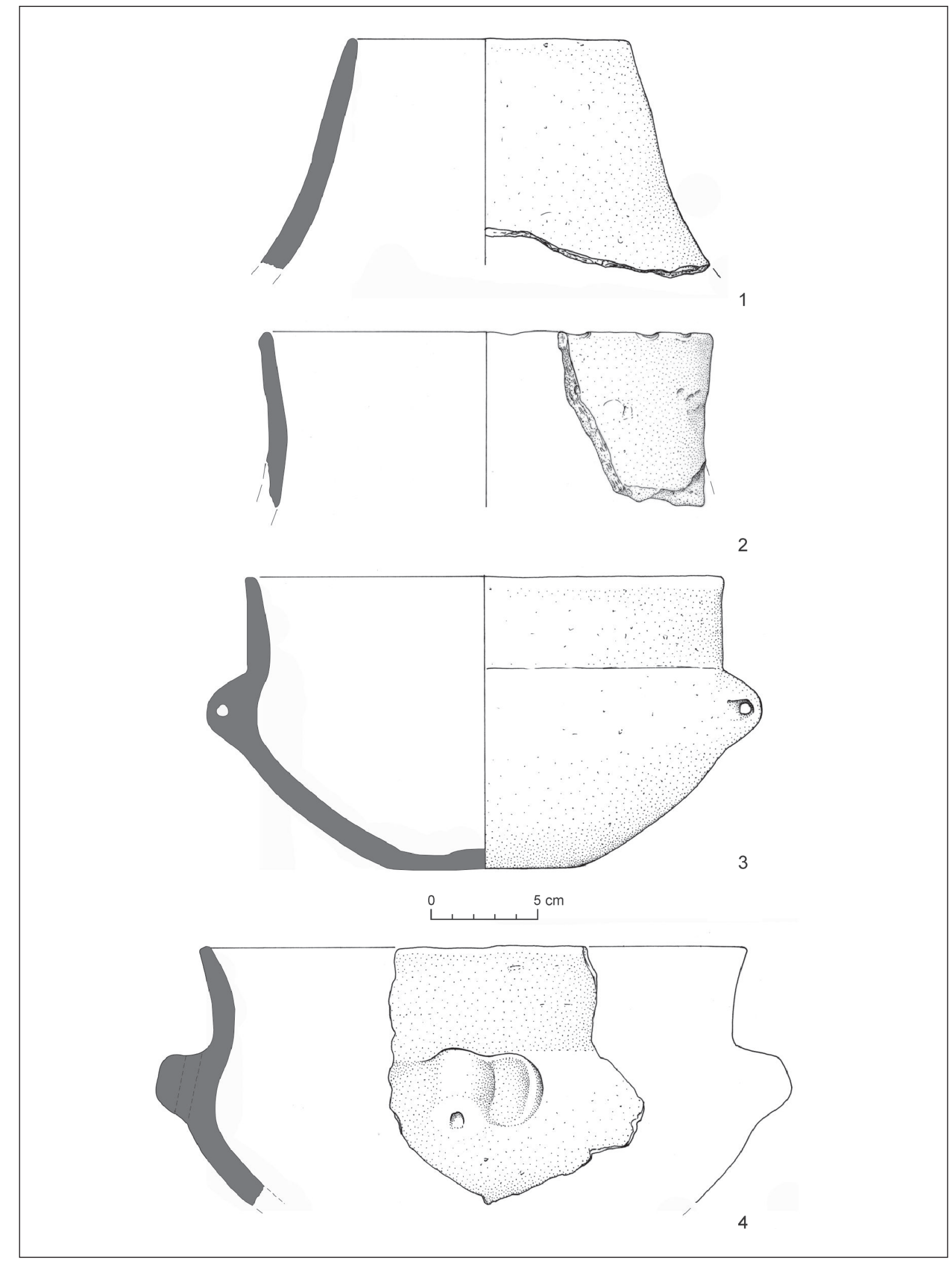

Tab. VII. Ruská, poloha Čierna zem. Kresbová dokumentácia objektu 94. 1-9 - výber nálezov z objektu 94. Mierka: a $1-3,7,9 ;$ b - 4-6, 8 (kresby keramiky a grafická úprava P. Šimčík). 


\section{LITERATÚRA}

Bánesz 1970

Baňacký a i. 1988

Béreš/Kaminská/Uličný 2000

Bognár-Kutzián 1963

Bognár-Kutzián 1969

Brummack 2015

Brummack/Diaconescu 2014

Budinský-Krička 1961a

Budinský-Krička 1961b

Budinský-Krička 1961c

Budinský-Krička 1963

Budinský-Krička 1964

Budinský-Krička 1968

Budinský-Krička 1969

Geologická mapa Slovenska

Granec/Šurina 1999

Higham a i. 2007

Horváth/Svingor 2015

Horváthová 2010

Horváthová 2015

Horváthová/Nevizánsky 2017

Horváthová/Zastawny 2016

Hreha 2016

Kalicz 1980

Kalicz/Horváth 2010

Kaminská 1987
L. Bánesz: Eneolitické nálezy z Barce-Svetlej IV. Študijné zvesti AÚ SAV 18, 1970, 326-330.

V. Baňacký/M. Elečko/M. Kaličiak/J. Lexa/P. Straka/D. Vass/J. Vozár/A. Vozárová: Geologická mapa južnej časti Východoslovenskej nížiny a Zemplínskych vrchov. Bratislava 1988.

J. Béreš/L'. Kaminská/M. Uličný: Záchranný výskum na trase plynovodu. Archeologické výskumy a nálezy v roku 1998, 2000, 33, 34.

I. Bognár-Kutzián: The Copper Age Cemetery of Tiszapolgár-Basatanya. Budapest 1963. I. Bognár-Kutzián: Probleme der mittleren Kupferzeit im Karpatenbecken. Študijné zvesti Aú SAV 17, 1969, 31-60.

S. Brummack: New Radiocarbon Dates from Eastern Slovakia. The Cases of Malé Raškovce and Barca Baloty. In: S. Hansen/P. Raczky/A. Anders/A. Reingruber (eds.): Neolithic and Copper Age between the Carpathians and the Aegean Sea. Chronologies and Technologies from the $6^{\text {th }}$ to $4^{\text {th }}$ Millennium BC. International Workshop Budapest 2012. Bonn 2015, 1-19.

S. Brummack/D. Diaconescu: A Bayesian approach to the AMS dates for the Cooper Age in the Great Hungarian Plain. Praehistorische Zeitschrift 89, 2014, 242-260.

V. Budinský-Krička: Východoslovenská nížina v praveku. Archeologické rozhledy 13, 1961, 41-49.

V. Budinský-Krička: Archeologické výskumy a objavy na východnom Slovensku v roku 1960. Študijné zvesti AÚ SAV 6, 1961, 294-297.

V. Budinský-Krička: Między Wihorlatem a pasmem Tokajsko-Przeszowskim. Acta Archaeologica Carpathica 3, 1961, 65-70.

V. Budinský-Krička: Žiarové hroby z doby medenej v Malých Zalužiciach-Lažňanoch. Archeologické rozhledy 15, 1963, 630-686.

V. Budinský-Krička: Pohrebisko z neskorej doby kamennej v Malých ZalužiciachLažňanoch. Študijné zvesti Aú SAV 13, 1964, 87-110.

V. Budinský-Krička: Výskum eneolitického a slovansko-avarského pohrebiska v Šebastovciach. Archeologické rozhledy 20, 1968, 213-219.

V. Budinský-Krička: Záchranný výskum v rokoch 1965 a 1966 v Barci, okres Košice. Nové Obzory 11, 1969, 231-235, 266-269.

Geologická mapa Slovenska M 1:50 000. Štátny geologický ústav Dionýza Štúra. Bratislava 2013. http://apl.geology.sk/gm50js [20. 04. 2018].

M. Granec/B. Surina: Atlas pôd Slovenskej republiky. Bratislava 1999.

T. Higham/J. Chapman/Vl. Slavchev/B. Gaydarska/N. Honch/Y. Yordanov/Br. Dimitrova: New Perspectives on the Varna Cemetery (Bulgaria). AMS dates and social implications. Antiquity 81, 2007, 640-654.

T. Horváth/É. Svingor: The spatial and chronological distribution of the so-called „Baden culture“. In: M. Nowak/A. Zastawny (eds.): The Baden culture around the Western Carpathians. Via Archaeologica. Kraków 2015, 19-74.

E. Horváthová: Osídlenie badenskej kultúry na Slovenskom území severného Potisia. Nitra 2010.

E. Horváthová: New data to cognition of the Baden Culture settlement in Prešov (north-eastern Slovakia, Šariš). In: M. Nowak/A. Zastawny (eds.): The Baden culture around the Western Carpathians. Via Archaeologica. Kraków 2015, 381-393.

E. Horváthová/G. Nevizánsky: Stránska. Osada badenskej kultúry z obdobia eneolitu v kontexte vývoja severného Potisia. Nitra 2017.

E. Horváthová/A. Zastawny: Rádiouhlíkové datovanie d’alších lokalít badenskej kultúry z územia Slovenska. Archeologie ve středních Čechách 20, 2016, 959-966.

R. Hreha: Sídliskové objekty kultúry Lažňany-Hunyadihalom v Bidovciach. Archeologické výskumy a nálezy v roku 2011, 2016, 100.

N. Kalicz: Újabb adatok a rézkori Hunyadihalmi csoport időrendjéhez. Neue Beiträge zur Chronologie der kupferzeitlichen Hunyadihalom-Gruppe. A Szolnok Megyei Múzeumok Évkönyve 1979-1980, 1980, 43-62.

N. Kalicz/L. Horváth: Die kupferzeitliche Protoboleráz-Phase (Gruppe) im Lichte der neuen Ausgrabungen in Südwest-Transdanubien. In: J. Šuteková/P. Pavúk/P. Kalábková/B. Kovár (eds.): Panta Rhei. Studies in Chronology and Cultural development of South-Eastern and Central Europe in earlier Prehistory presented to Juraj Pavúk on the occasion of his $75^{\text {th }}$ birthday. Studia Archaeologica et Mediaevelia XI. Bratislava 2010, 407-434.

L. Kaminská: Príspevok k osídleniu Hrčela v mladej a neskorej dobe kamennej. Archeologické rozhledy 39, 1987, 481-506. 
Kaminská 2007

Kovács/Váczi 2008

Lamiová-Schmiedlová 1964

Němejcová-Pavúková 1985

Patay 1961

Patay 1975

Patay 1976

Patay 2005

Raczky/Siklósi 2013

Schier 2013

Šiška 1964

Šiška 1968

Šiška 1970

Šiška 1971

Šiška $1972 a$

Šiška $1972 b$

Šiška 1973

Šiška 1976

Šiška 1977

Šiška 1998

Vizdal, J. 1961

Vizdal, J. 1980

Vizdal, M. 1986

Yerkes a i. 2009

Wild a i. 2001

Zalai-Gaál 2016
L. Kaminská: Praveké osídlenie pieskovej duny Vel'ká Mol'va v Čičarovciach. Slovenská archeológia 55, 2007, 203-260.

K. Kovács/G. Váczi: The cemetery of the Early Copper Age Tiszapolgár Culture at Hajdúböszörmény-Ficsori-tó-Dülő. In: J. K. Kozłowski/P. Raczky (eds.): The Lengyel, Polgár and related cultures in the middle/late Neolithic in Central Europe. Kraków 2008, 397-410.

M. Lamiová-Schmiedlová: Kontrolný výskum v Ostrovanoch v roku 1963. Študijné zvesti Aú SAV 13, 1963, 233-251.

V. Němejcová-Pavúková: The Eastern influences upon the Carpathian basin in the Eneolithic - The problem of their dating and significance. In: J. K. Kozłowski/J. Machnik (eds.): L'eneolithique et le debut de l'age du bronze dans certaines regions de l'Europe. Krakow 1985, 21-29.

P. Patay: A bodrogkeresztúri kultúra temetői. Régészeti Füzetek II/10. Budapest 1961.

P. Patay: Die hochkupferzeitliche Bodrogkeresztúr-Kultur. Bericht der Römisch-Germanischen Kommission 55, 1975, 1-77.

P. Patay: A magyarhomorogi rézkori temető. Das kupferzeitliche Gräberfeld von Magyarhomorog. A Debreceni Déri Múzeum Évkönyve 56, 1976, 173-254.

P. Patay: Kupferzeitliche Siedlung von Tiszalúc. Budapest 2005.

P. Raczky/Z. Siklósi: Reconsideration of the Copper Age chronology of the eastern Carpathian Basin: a Bayesian approach. Antiquity 87, 2013, 555-573.

W. Schier: An Antiquarian's Grave? Early Tiszapolgár Burials in the Late Vinča Tell Site of Uivar (Romania). In: A. Anders/G. Kulcsár (eds.): Moments in Time. Papers presented to Pál Raczky on his $60^{\text {th }}$ Birthday. Prehistoric Studies 1. Budapest 2013, 569578.

S. Šiška: Pohrebisko tiszapolgárskej kultúry v Tibave. Slovenská archeológia 12, 1964, 5-69.

S. Šiška: Tiszapolgárska kultúra na Slovensku. Slovenská archeológia 16, 1968, 61-175. S. Šiška: Nové výskumy na lokalitách lažnianskej skupiny. Východoslovenský pravek 1, 1970, 29-36.

S. Šiška: Výskum pohrebiska lažnianskej skupiny v Barci roku 1969. Východoslovenský pravek 2, 1971, 23-27.

S. Šiška: Gräberfelder der Lažňany-Gruppe in der Slowakei. Slovenská archeológia 20, 1972, 107-175.

S. Šiška: Výsledky výskumu eneolitických pohrebísk v Šebastovciach a Barci. Archeologické rozhledy 24, 1972, 4-9, 97, 98.

S. Šiška: Die Lažňany-Kulturgruppe in der Ostslowakei. In: B. Chropovský (Hrsg.): Symposium über die Entstehung und Chronologie der Badener Kultur. Bratislava 1973, 453-464.

S. Šiška: Sídlisko z mladšej doby kamennej v Prešove-Šarišských lúkach. Slovenská archeológia 24, 1976, 83-117.

S. Šiška: Archeologický prieskum Východoslovenskej nížiny v roku 1976. Archeologické výskumy a nálezy v roku 1976, 1977, 272-275.

S. Šiška: Nálezy bolerázskej skupiny na východnom Slovensku. Sborník prací Filosofické Fakulty brněnské university M 2, 1998, 125-133.

J. Vizdal: Neolitická jama z Oborína. Archeologické rozhledy 13, 1961, 318-325, 349351.

J. Vizdal: Potiská kultúra na východnom Slovensku. Košice 1980.

M. Vizdal: Výskumy a nálezy Zemplínskeho múzea v Michalovciach. Archeologické výskumy a nálezy v roku 1985, 1986, 237-252.

R.W. Yerkes/A. Gyucha/W. A. Parkinson: A multiscalar approach to modeling the and of the Neolithic on the Great Hungarian Plain using calibrated radiocarbon dates. Radiocarbon 51, 2009, 1071-1109.

E. M. Wild/P. Stadler/M. Bondár/S. Draxler/H. Friesinger/W. Kutschera/A. Priller/W. Rom/E. Ruttkay/P. Steier: New chronological frame for the young neolithic Baden culture in Central Europe ( $4^{\text {th }}$ Millenium BC). Radiocarbon 43, 2001, 10571064.

I. Zalai-Gaál: Tiszapolgár - Bodrogkeresztúr - Hunyadihalom: Wirkungen und Gegenwirkungen am Ende der Hochkupferzeit im Ostkarpatenbecken. In: K. Bacvarov/R. Gleser (eds.): Southeast Europe and Anatolia in prehistory. Essays in honor of Vassil Nikolov on his $65^{\text {th }}$ anniversary. Bonn 2016, 389-402. 


\title{
Newly discovered settlement finds of the Lažňany group from Ruská, Michalovce district
}

\author{
Eva Horváthová - Lýdia Gačková
}

Summary

Archeológia Zemplín, s. r. o., company carried out a rescue excavation along the route of a line structure of a gas pipeline reconstruction in 2008 and 2009. The line of the structure was stretched from the state road between Vel'ké Kapušany and Ruská to the state border with Ukraine. Its total length reached $20.271 \mathrm{~km}$. During earthworks in the territory of the village of Ruská, Čierna zem site, 122 polycultural archaeological features from various periods of prehistory to the early history were documented within length of $302 \mathrm{~m}$.

Features of the Lažňany group were situated within $60 \mathrm{~m}^{2}$ in the northeastern part of the archaeologically investigated area. Their concentration in one larger complex including holes 90-96 was visible. Stake holes 59 and 60 were definitely related to this complex. Other stake holes occurring nearby did not contain archaeological finds. Settlement features (with the exception of stake holes) had irregular oval, elliptic and asymmetrical ground plan and gradually or unevenly excavated walls. Multiple hollows were found in their bottom parts. The preserved sizes of smaller pits, excluding the damaged feature 96 , varied from 1.60 to $2.44 \mathrm{~m}$ of length, 1.10 to $2.08 \mathrm{~m}$ of width and 0.35 to $0.66 \mathrm{~m}$ of depth. The central feature's size was 5.34 by $2.44 \mathrm{~m}$ and it was $1.05 \mathrm{~m}$ deep. If we take all our knowledge of construction skills of the Hunyadihalom culture population into consideration and confront it with the find contexts described in Ruská the part interfering with the area of the Lažňany group settlement, we can see significant conformity between both settlements in the common occurrence of exploitation pits excavated near more or less concentrated stake holes. It suggests possible existence of above-ground stake constructions at the site of Čierna zem. We assume so also with regard to the construction practise of the people with material expression of the Tiszapolgár culture. At least nine ground plans of above-ground stake constructions or their parts from its settlement have been documented in the Východoslovenská nížina lowland. It is obvious from the investigation documents from the studied area in Lúčky that this type of dwellings occurred in settlements together with above-ground houses which had floors more or less sunken under the then terrain. Thus, it is very probable that the tradition of building of both kinds of dwellings could have been common with the people of the Lažňany material habit in the end of the Early Eneolithic.

Pottery of the Lažňany group in Ruská is represented by fragments of bowls, pot-shaped vessels, amphoras, rectangular chalices, one lid and storage vessels. As far as miniature artifacts made of clay are concerned, a fragment of a small wheel has been preserved. A small number of lithic industry was found in the backfill of the features. Shapes of the pottery finds resemble the typological range of alms discovered in cremation burials in Malé ZalužiceLažňany (Michalovce district) and Velyki Lazy (Carpathian Ruthenia). The preserved fragments of vessels are not as richly decorated as the finds from Tiszalúc. We can see a remarkable difference in the absence of engraved and fluted (cannelures) decorative patterns. Occurrence of cut or fingerpressed rims of pot-shaped vessels is rare in the assessed collection and maximum moderation is observed in application of various plastic elements on pottery (handles with lobulate protuberances of the Scheibenhenkel type, pseudo-handles and pseudo-protuberances). We have not detected any traces of black resin coating on the surface of the preserved sherds.

The chronological status of the Lažňany group settlement in Ruská can be only indirectly derived from the comparison of recently executed radiocarbon AMS data (from Košice Barca-Balota), which determine the time span between years $4000 / 3950 \mathrm{cal}$. BC to 3800/3750 cal. BC for the settlement horizon of the Hunyadihalom-Lažňany cultural complex in the Northern Tisza region (Brummack 2015, 13). If we confront these data with other AMS data related to the oldest Boleráz-early classical horizon of the Baden culture in the south of Eastern Slovakia (Kašov, settlement feature 1/2011, 4575 BP-4480 BP or 3498 cal. BC-3029 cal. BC; Baden I/II), we discover an excessively long - almost 300 years - time hiatus between the end of the Lažňany group settlement and occurrence of a new population and trend with the pottery style of the Boleráz-early classical horizon of the Baden culture. On the contrary, the oldest radiocarbon data from the Boleráz group sites in Western Slovakia are associated with the proto-Boleráz phase of the settlement. In conclusion, we must add that the sites from the turn of the Early and Middle Eneolithic with pottery of the Boleráz type which were previously noticed by S. Šiška $(1972 b, 8 ; 1973,461,462 ; 1998 b, 129)$ are not known from the Košická kotlina basin only; recently, other reliably identified sites are being added not only from the periphery of the Košická kotlina basin (Prešov, Mestský cintorín /Town cemetery/ site, unpublished), but also from the Východoslovenská nížina lowland (Kašov-Šarkan, Trebišov-Koval'ka; unpublished). With the exception of the AMS data from Kašov, no quality organic samples suitable for radiocarbon AMS analyses have occured at the above mentioned sites from the Bolerázearly classical horizon Baden I/II, including the settlements of the Lažňany group (i. e. including the settlement in Ruská). The historical-archaeological development of the south of Eastern Slovakia between 3800 and 3500 BC remains unexplained in the current state of research. 
Fig. 1. Ruská, Michalovce district. Location of the site on a blank map of Eastern Slovakia.

Fig. 2. Ruská, Michalovce district. Map section 38-41-18. 1 - Pri cintoríne site, place of investigation studied in 1998; 2 - Čierna zem site, place of investigation studied in 1998; 3 - Čierna zem site studied in 2008 and 2009: a - archaeologically studied area; $b$ - location of eneolithic features within the investigation area.

Fig. 3. Ruská, Michalovce district. Section of the investigation's situation plan with marked places of investigation of eneolithic features (authors of the plan L. Gačková, P. Šimčík).

P1. I. Ruská, Čierna zem site. Drawn documentation of feature 90. 1-4 - selection of finds from feature 90. Scale: a - 1; b - 2-4 (drawings of pottery and graphic design by P. Šimčík).

Pl. II. Ruská, Čierna zem site. Drawn documentation of features 91, 95, 96. 1-3 - selection of finds from feature 91 (drawings of pottery and graphic design by P. Šimčík).

Pl. III. Ruská, Čierna zem site. Drawn documentation of feature 92. 1-4 - selection of finds from feature 92. Scales: a - 1, $2 ; b-3,4$ (drawings of pottery and graphic design by P. Šimčík).

Pl. IV. Ruská, Čierna zem site. 1-18 - selection of finds from feature 92. Scale: a - 1-6; b - 7-18 (drawings of pottery and graphic design by P. Šimčík).

Pl. V. Ruská, Čierna zem site. Drawn documentation of feature 93. 1-8 - selection of finds from feature 92; 9-16 - selection of finds from feature 93. Scale: $a-1-8 ; b-9-16$ (drawings of pottery and graphic design by P. Šimčík).

P1. VI. Ruská, Čierna zem site. 1-4 - selection of finds from feature 93 (drawings of pottery and graphic design by P. Šimčík).

P1. VII. Ruská, Čierna zem site. Drawn documentation of feature 94. 1-9 - selection of finds from feature 94. Scale: a $1-3,7,9 ; b-4-6,8$ (drawings of pottery and graphic design by P. Šimčík).

Translated by Viera Tejbusová

PhDr. Eva Horváthová, PhD.

Archeologický ústav SAV

Hrnčiarska 13

SK - 04001 Košice

ehorvath@saske.sk
PhDr. Lýdia Gačková

Zemplínske múzeum v Michalovciach

Kostolné námestie 1

SK - 07101 Michalovce

lydia.gackova@gmail.com 